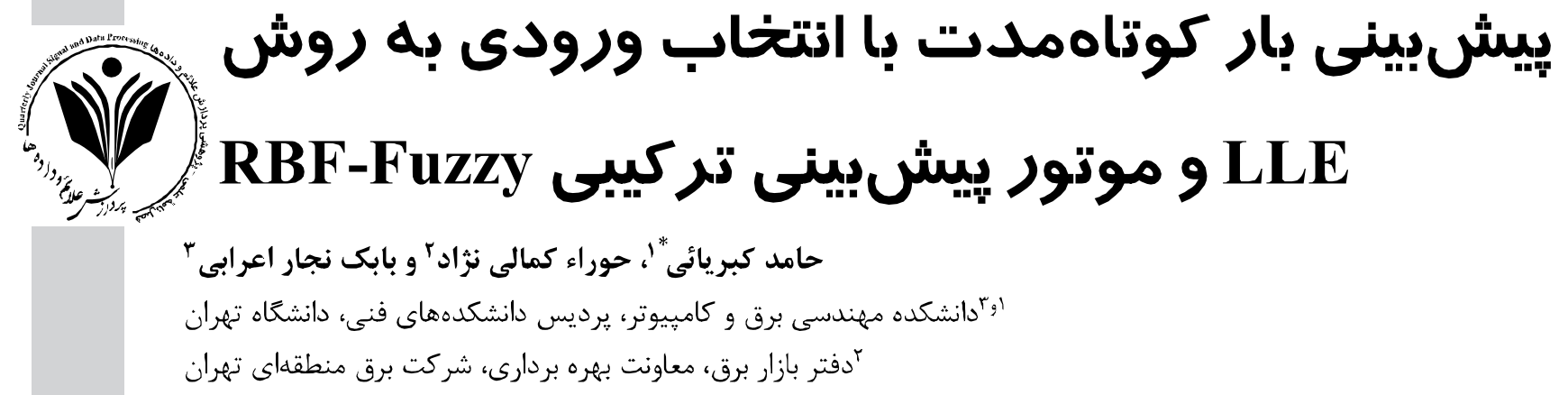

جكيده

در اين مقاله يك روش يادكيرى خم تحت عنوان Locally Linear Embedding (LLE) براى استخراج ورودى هاى داراى اطلاعات بيشتر و كاهش

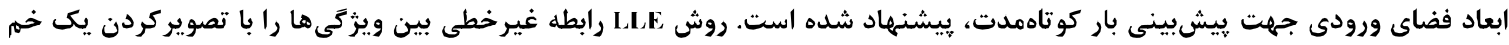

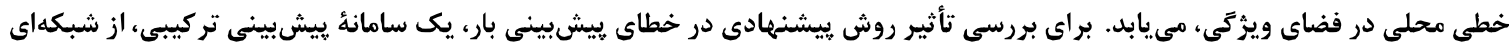

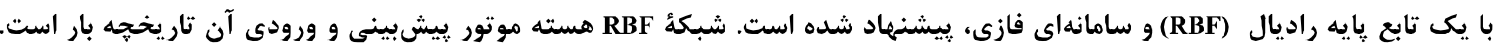

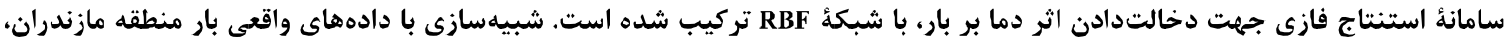

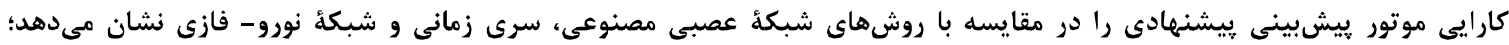

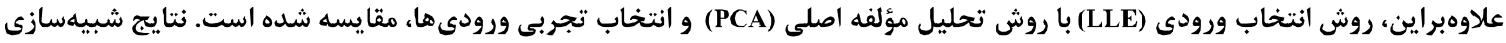

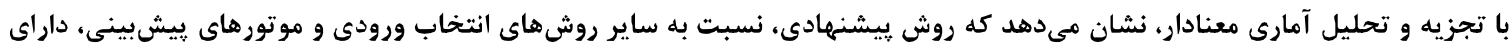

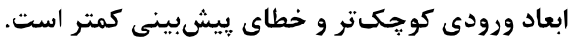
وازكان كليدى: يادكيرى خهم به روش (LLE)، انتخاب ورودى، شبكه RBF، سامانهُ فازى، بيشبينى بار الكتريكى كوتاهمدت.

\title{
Short term load forecast by using Locally Linear Embedding manifold learning and a hybrid RBF-Fuzzy network
}

\author{
Hamed Kebriaei $^{* 1}$, Howra Kamalinejad ${ }^{2}$ \& Babak Nadjar Araabi ${ }^{3}$
}

${ }^{1,3}$ School of Electrical and Computer Engineering, College of Engineering, University of Tehran ${ }^{2}$ Electricity Market Office, Deputy of Operations, Tehran Regional Electricity Company

\section{Abstract}

The aim of the short term load forecasting is to forecast the electric power load for unit commitment, evaluating the reliability of the system, cconomic dispatch, and so on. Short term load forecasting obviously plays an important role in traditional non-cooperative power systems. Moreover, in a restructured power system a generator company (GENCO) should predict the system demand and its corresponding price for efficient decision making.

The task of a forecasting engine is to find the relation of the inputs and outputs of the system and also predicts the outputs for a given inputs. Therefore, the accuracy of forecasting is highly affected by the inputs of the forecasting engine. This effect can be studied from two points of view; First, extracting the more informative inputs and second, reducing the dimension of input space, both make it possible to learn the forecasting network via more simple models with more generalization. As a result, a reduced informative

* Corresponding author *نويسنده عهلهدار مكاتبات 
input space leads to lower prediction error. In many previous load forecasting methods, the inputs have been selected empirically. In this manner, the more correlative factors with the load in the forecasting day have been chosen as the inputs. They are generally a combination of load history and weather conditions. Several researches are focused on mathematical approaches of the input selection which are mainly based on principal component analysis (PCA) method as well as some intelligent algorithms.

In this paper, a manifold learning method namely Locally Linear Embedding (LLE) is proposed, aiming to extract more informative inputs and to reduce the dimension of input space for short term load forecasting. Among all methods based on manifold learning, it can be seen that LLE performs very well in extracting the clectric load curve features. The aim of this paper is to analyze the features of the load curve for estimating this curve in future. The extensive computational experiments show that the extracted features by LLE results in less prediction error than two other methods. Furthermore, LLE acts faster and makes input dimension lower than the two other methods. In the following section we will discuss the LLE method. The LLE method finds the nonlinear relationships among features by mapping a locally linear manifold in the feature space. Extracting the more informative inputs by extracting the combinational features by finding the nonlinear dependences of the features, results in reducing the dimension of input space. The resulted inputs from feature cxtraction and dimension reduction are utilized for load forecasting.

To examine the effect of the proposed feature extraction method on load prediction error, a hybrid prediction system is proposed which is a combination of a radial basis function (RBF) network and a fuzzy system. The RBF network is the core of the prediction engine and works with historical load data as its inputs. The fuzzy inference system is combined with the RBF network to incorporate the impact of temperature on load. The case studies are carried out on the real data of electric power load of Mazandaran area in Iran. The efficiency of the proposed forecasting engine is compared with three benchmarks, the artificial neural network, time series and neuro-fuzzy methods. Furthermore, the proposed input selection method (LLE) is compared with principal component analysis (PCA) and empirical selection of inputs. Simulation results with statistical significance analysis show that the LLE method with the proposed forecasting engine is superior to other input selection methods and forecasting engines in sense of lower input dimension and lower prediction error.

Keywords: Manifold learning, input selection, RBF network, fuzzy system, short term load forecasting.

$$
\begin{aligned}
& \text { مسأله انتخاب ورودى در بيشتر روشهاى رِيشبينى } \\
& \text { بار، تجربى است. به اين ترتيب كه متغيرهايى را كه بهطور } \\
& \text { تجربى همبستكى بيشترى با بار روز ״يشبينى دارند، بهعنوان } \\
& \text { ورودى انتخاب ميىشوند كه بهطورمعمول بهصورت تركيبى از } \\
& \text { تاريخجه بار و شرايط آب و هوايى است. جندين ثرثوهش در }
\end{aligned}
$$

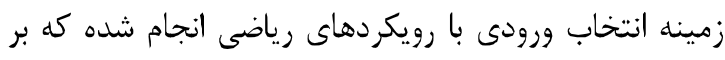

$$
\begin{aligned}
& \text { اساس روش تحليل مؤلفههاى اساسى 'PCA و همجِنين برخى } \\
& \text { از الغوريتهماى هوشمند است. } \\
& \text { در [1,2] روش PCA براى انتخاب ورودى يك شبكه } \\
& \text { عصبى براى ييشبينى بار كوتاهمدت بهكار رفته است. در [3] }
\end{aligned}
$$

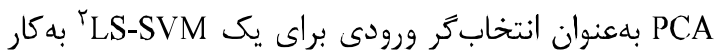

$$
\begin{aligned}
& \text { رفته و نشان داده شده است كه استفاده از PCA دقت } \\
& \text { ييشبينى و بلنوعى توان تعميميذيرى سامانه را نسبت به } \\
& \text { حالتى كه انتخاب ورودى صورت نمى خيرد، افزايش داده است. } \\
& \text { در [PCA [4 براى انتخاب ورودى در روشهاى ARIMA و } \\
& \text { AR تناوبى جهت تأثيردادن تناوب فصول در سرىهاى زمانى، }
\end{aligned}
$$

\footnotetext{
1 Principal Component Analysis

${ }^{2}$ Least Squarc-Support Vector Machine
}

$$
\begin{aligned}
& \text { ( } 1 \\
& \text { هدف اصلى از ييشبينى بار كوتاهمدت، برآوردى از بار است }
\end{aligned}
$$

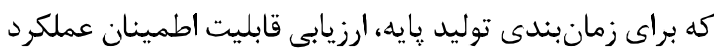

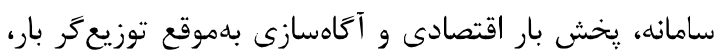

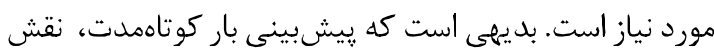

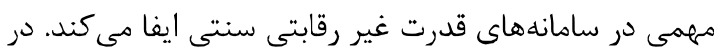

$$
\begin{aligned}
& \text { يك سامانه قدرت تجديد ساختاريافته نيز، يك توليدكننده، }
\end{aligned}
$$

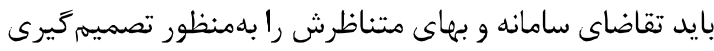

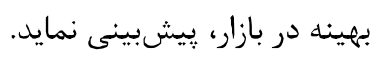

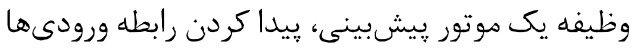

$$
\begin{aligned}
& \text { و خروجىهاى سامانه و ييشبينى خروجى ها براى يك ورودى }
\end{aligned}
$$

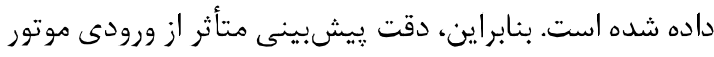

$$
\begin{aligned}
& \text { بيشبينى است. اين اثر را مى توان از دو نقطهنظر مطالعه كرد. }
\end{aligned}
$$

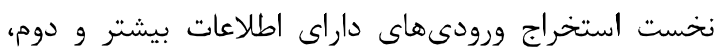

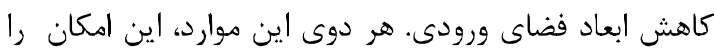

$$
\begin{aligned}
& \text { مى دهد كه يادكيرى در شبكه ييشبينى، از طريق مدل هاى }
\end{aligned}
$$

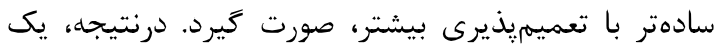

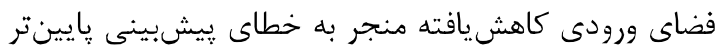

$$
\begin{aligned}
& \text { مىشود. }
\end{aligned}
$$




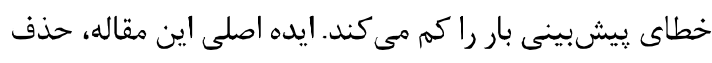

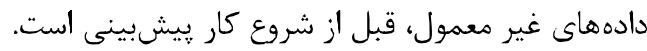

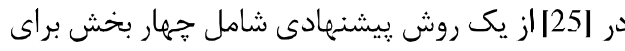
ييشبينى همززمان قيمت و وبار استفاده شده است. نتايج شبيهسازى براى بار منطقه نيوانكلند و نيوسوثويلز استراليا

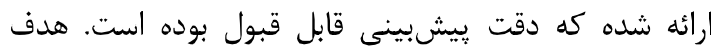

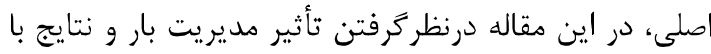
روشهاى ديخر مقايسه نشده است.

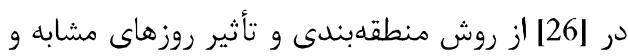
دما، براى يیش بينى بار كل شبكه برق ايران استفاده شده

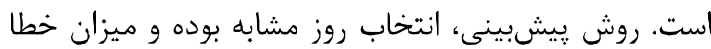
بهصورت ميانكين سالانه در كل كشور محاسبه شده است.

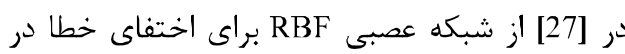
فريمهاى ويدئو استفاده شده كه نشاندهنده كاهش حجم آنمائ محاسبات در اين شبكه عصبى است. در [28] از تركيب شبكههاى عصبى و التَوريتم زنتيكى ندئه

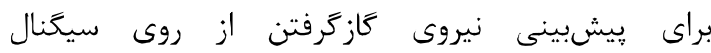
الكترومايو كرام استفاده شده كه نشاندهنده كاربرد شبكهنهاى

$$
\text { عصبى در حيطه يزشكى است. }
$$

آنَّونه كه در بررسى مقالات معتبر داخلى ديده شد،

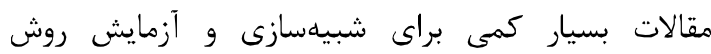

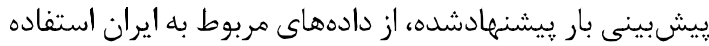

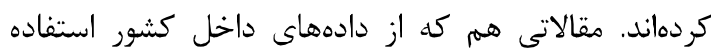

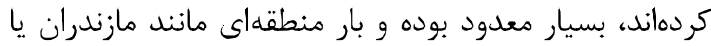

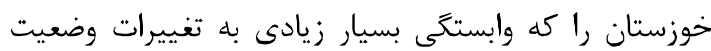

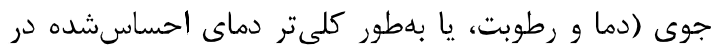

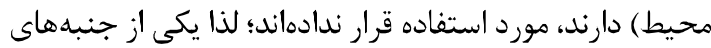

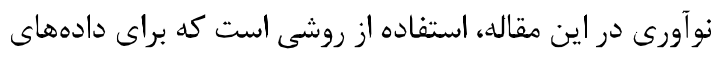

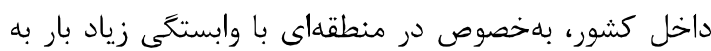
وضعيت جوى، باسخ قابل قبول داشته باشد.

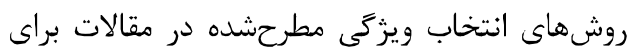

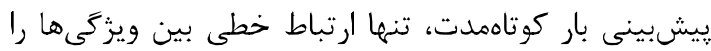
مىيابند. در عين حال، وجود روابط غير خطى بينى بين ورودى بئها،

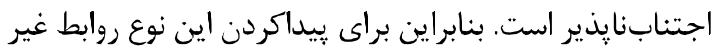

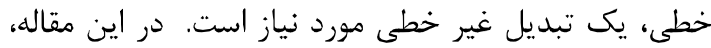

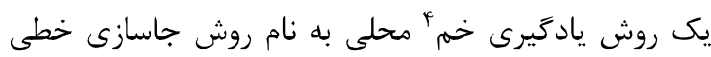
محلى (LLE) ه براى اين منظور مورد استفاده قرار ميى خيرد. استفاده از اين روش مزاياى زير را دارد:

${ }_{5}^{4}$ Manifold learning

${ }^{5}$ Locally Linear Embedding
بهكار رفته است. در [5] از الكوريتم KPCA' براى انتخاب

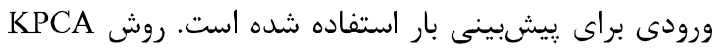
تعميمى براى روش PCA است، كه در آن ابتدا يك تبديل

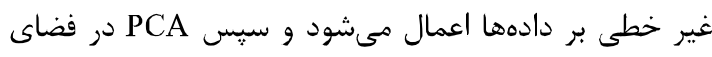
جديد كاهش بعد انجام ميدهد. براى محاسبه ضرب داندان داخلى

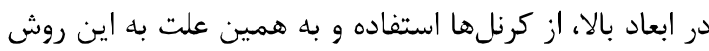
KPCA KPCA بهعنوان ورودى

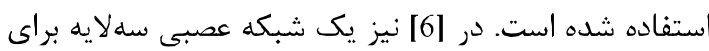

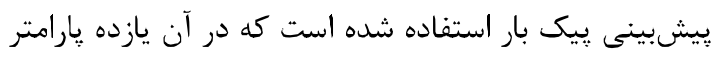

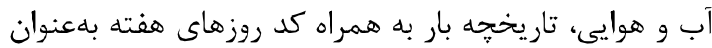

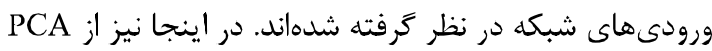

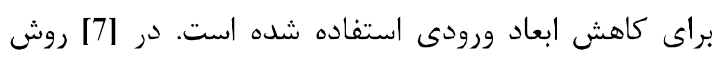

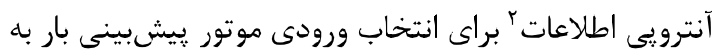

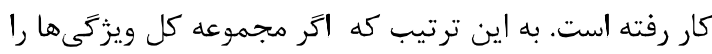

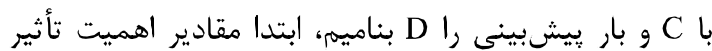
يارامتر

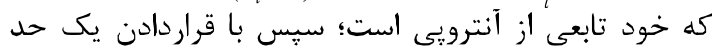
آستانه،

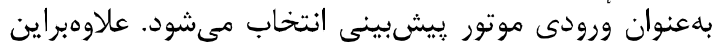
در [8] از روش تحليل مؤلفه مستقل (ICA

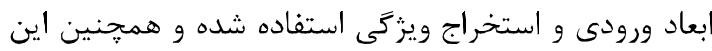

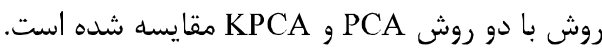
در [22] از تجزيه سرى زمانى و شبكأ عصبى براي مقاى

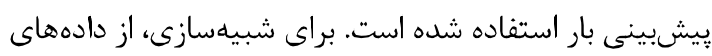

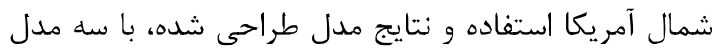
بر يايه شبكأ عصبى مقايسه شده است. در [23] از تركيب شبكئ عصبى بهبوديافته با كلونى مقيس زنبور عسل براى يافتن بهترين وزنها و باياسها براى كمينهكردن خطاى بيشبينى بار استفاده شده است. نتايج شبيهسازى بر روى دادهاى يك هفته از بار منطقه نيوانكلند

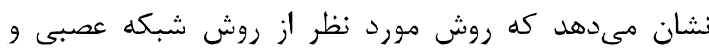
عصبى - فازى، نتايج بهترى دارد.

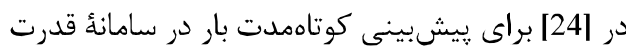

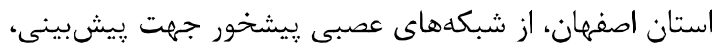

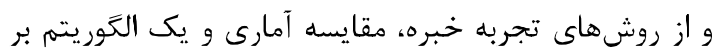

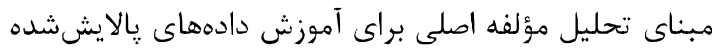

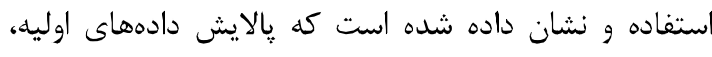

${ }^{1}$ Kernel Principal Component Analysis

${ }^{2}$ Information Entropy

${ }^{3}$ independent component analysis 
مقادير عددى، دادهاى اوليه بايد هنجارسازى شود. مرحله ז: ماتريس همبستكى را ايجاد كرده و مقادير ويزه و بردارهاى ويزّه آن را محاسبه مى كنيه.

$R=\frac{1}{N-1} X^{* T} X^{*}$

كه در آن N تعداد نمونهها و ماتريس دادههاى

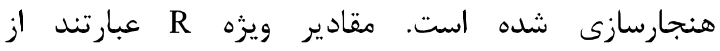
$\lambda_{1} \geq \lambda_{2} \geq \ldots \geq \lambda_{m}$ $u_{1}, u_{2}, \ldots, u_{m}$

مرحله r: تعداد مؤلفههاى اصلى را تعيين مى كنيم. توزيع واريانس تجميعشده را مىتوان بهصورت زير محاسبه كرد:

$\eta(p)=\sum_{i=1}^{p} \lambda_{i} / \sum_{i=1}^{m} \lambda_{i}$

تعداد مؤلفههاى اصلى به توزيع واريانس تجميعشده بستكى دارد. بلطورمعمول وقتى (p)

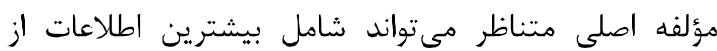
متغيرهاى اوليه باشد.

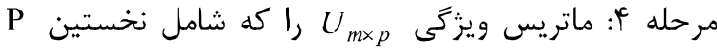

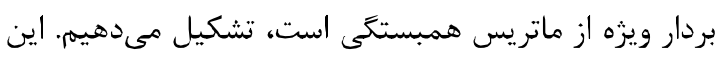
ماتريس مىتواند براى تبديل مجموعه دادههاى اوليه كه داراى

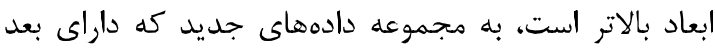

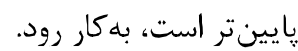
$Z_{N \times P}=X_{N \times m}^{*} U_{m \times P}$

$$
U_{m \times P}=\left[u_{1}, u_{2}, . . u_{P}\right] \text { كه در آن }
$$

با وجود محبوبيت PCA، اين روش محدوديتهايى دارد. دمهمترين نقص PCA اين است كه ضرورت دارد دارد، دادهها

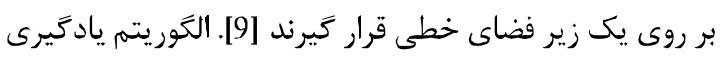

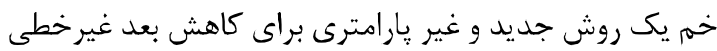

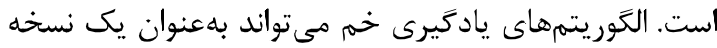

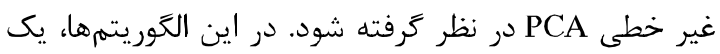

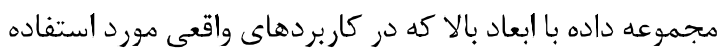

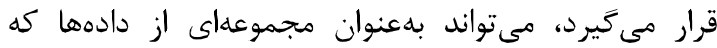

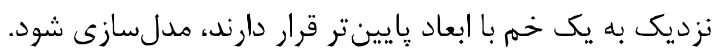
فرض كنيد مجموعه داده

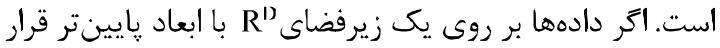

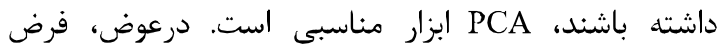

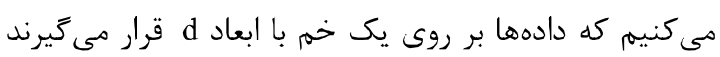

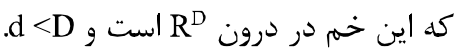

1- استخراج ورودىهاى داراى اطلاعات بيشتر، بهمك

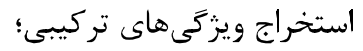
r- كاهش ابعاد فضاى ورودى، پِيداكردن وابستخى هاى غئى غير خطى ويزگ خى ها. ورودىهاى حاصل از استخراج ويزگى هاى ورودى و كاهش ابعاد ورودى، براى ييشبينى بار به كار مىروند.

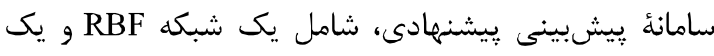

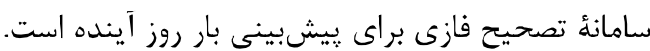

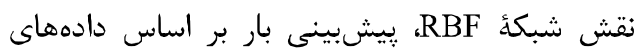

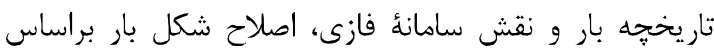

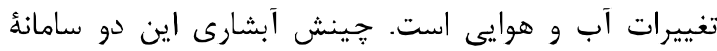

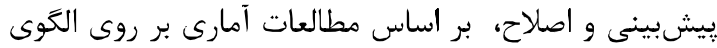

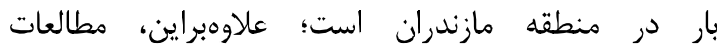
روانشناختى، اجتماعى و اقتصادى منطقه مازندران، تعدادى دانى زز قوانين منطقى تغيير بار را بر اساس تغييرات دما، به دست

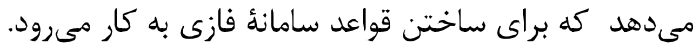

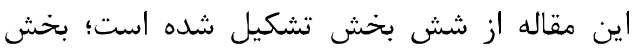

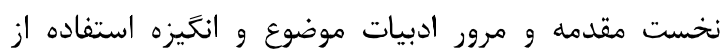
يادَّيرى خم به جاى PCA در بخش دو مورد بحث قرار ترفته

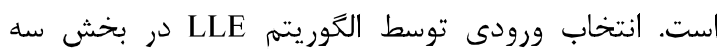

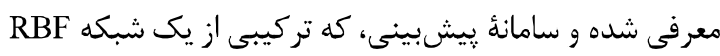

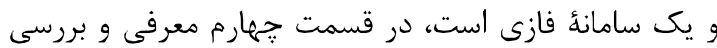

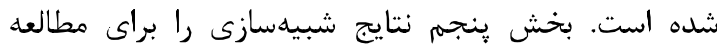

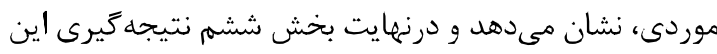

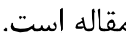

\section{r- بيشنياز مسأله}

محبوبترين الكوريتم براى كاهش ابعاد ورودى، روش تجيسي تجزيه

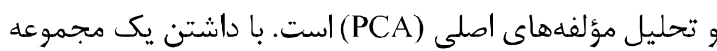

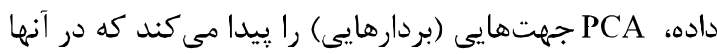

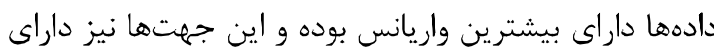

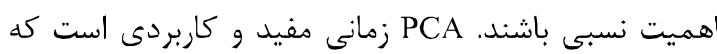
دادهها، بر روى يا در نزديكى يك زيرمجموعه خطى از مجموعه

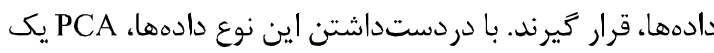

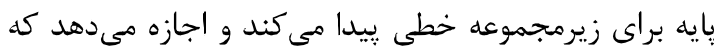
ويزگى هاى غير مرتبط را ناديده بخيريم [19]. روش PCA شامل مراحل زير است [3]:

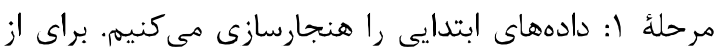

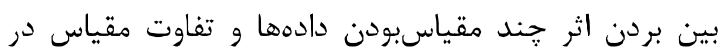


مىرود. انتخاب ورودى به روش LLE، در زير شرح داده خواهد شد:

فرض مى كنيهم مجموعه داده مربوط به N روز در فضاى

با بعد بالا داده شده است: بردارهاى ويزگى ذاتى جاسازىشده در فضاى با بعد يايين، يعنى بر است كه باشرح زير عمل مى كند [11,12]: ( ) نزديكترين k همسايكى ها براى هر نقطه

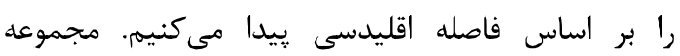

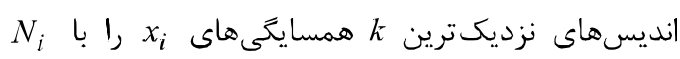
نشان مى دهيم. در زمينه انتخاب k كارهاى كمى انجام شده

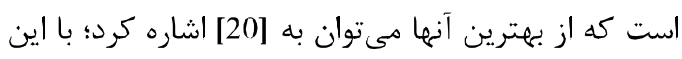

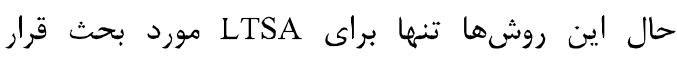

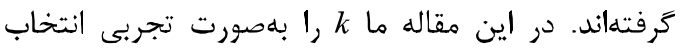
مى كنيم؛ بلنحوى كه بيشترين بازدهى را در دجموعه دادههاى آموزش بهدست آوريم. بهني

ץ) تركيبى محدب و بهينه محلى از نزديكترين $k$ همسايخى دهى به كمينهكردن تابع هزينه زير با ضرايب وزنى

$$
\begin{aligned}
& E(w)=\sum_{i=1}^{N}\left\|x_{i}-\sum_{j \in N_{i}} w_{i j} x_{j}\right\|^{2} \\
& \sum_{j \in N_{i}} w_{i j} x_{j}=1 \text { كه در آن \|.|| نرم }
\end{aligned}
$$

ضريب وزن $w_{i j}$ نشاندهندة سهم داده j-ام در نمايش داده i-ام است. وزنهاى بهينه را مي توان از حل مسأله كمينه مربعات مقيد به دست آورد، كه درنهايت به حل يك مسأله

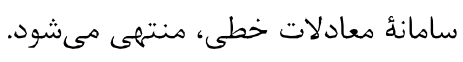

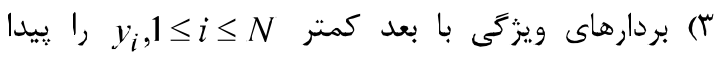

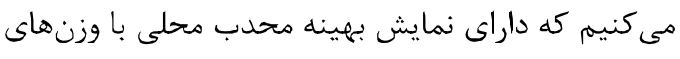
wij كمينه سازى تابع هدف زير بهدست مى آيند:

$\Phi(y)=\sum_{i=1}^{N}\left\|y_{i}-\sum_{j \in N_{i}} w_{i j} y_{j}\right\|^{2}$

كه مىتواند به فرم درجه دو زير نوشته شود:

$$
\Phi(y)=\sum_{i j} M_{i j}\left(y_{i} \cdot y_{i}\right)
$$

فرض مىكنيم كه دادها از يك خم نمونهبردارى

$x_{i}=f\left(y_{i}\right) \quad i=1,2, . ., N$

شدهاند:

كه مبتنى بر خم، روشى را براى يافتن بردارهاى ويثزَى با بّعد كمتر يشيشنهاد مي دهد.

קندين روش يادگيرى غير يارامترى براى يادگيرى خمم

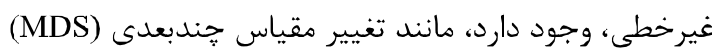

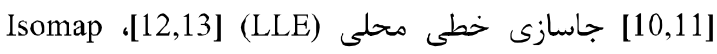
[14]، تبديلهاى ويزٌه لايلاسى [15]، تبديلهاى ويزه هسيان

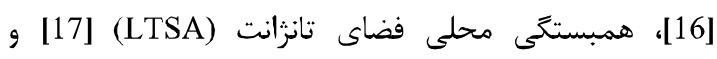
تبديلهاى انتشار [18]. مرورى بر روشهاى يادشده، در [19] بيان شده است. در ميان تمام روشهاى مبتنى بر يادگيرى خم، ديده مىشود كه LLE در استخراج ويزخى هاى منحنى استى بار الكتريكى بسيار خوب عمل مى كند. هدف از اين هقاله، تحليل ويزگى هاى منحنى بار براى تخمين اين منحنى در

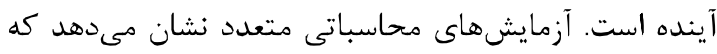
ويزگى هاى استخراجشده از طريق LLE موجب خطاى ييشبينى كمتر نسبت به دو روش ديخر مىشود. علاوهبراين،

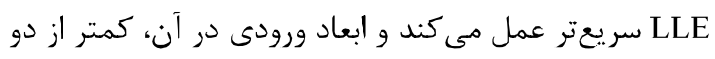
روش ديخر است. در بخش زير روش LLE را مورد بحث قرار

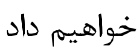

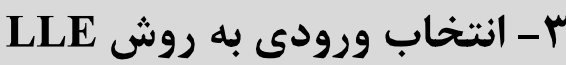

در مسأله ييشبينى بار، ورودىهاى مختلفى براى سامانه ييشبينى در نظر كرفته مىشود كه معمولترين آنها عبارتاند از: بار روزهاى كذشته، كد روز هفته، دما، رطوبت و... ورودى

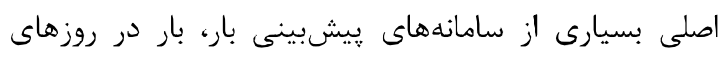

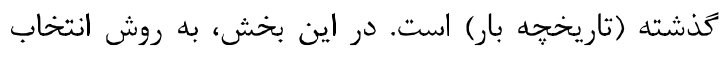
ورودى LLE، با جزئيات اشاره مىشود.

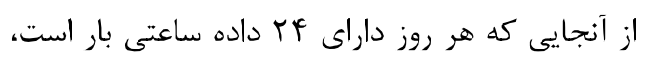
ابعاد ورودى، بزرى خواهد بود؛ بنابراين دادههاى n روز كذشته

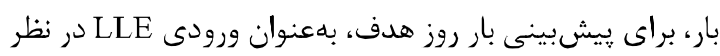

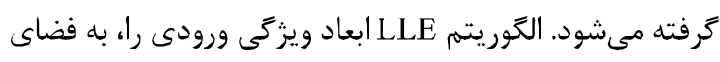

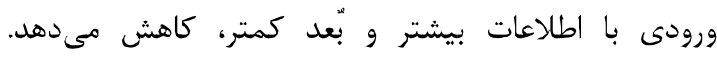

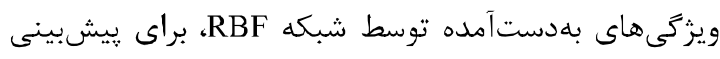
بار استفاده مىشود. ديخر ورودى براى ييش بيشى بينى بار، بيشينه دماى روز است كه بهطور مستقيم توسط سامانه فازى به كار 
است. سامانه فازى براى مقابله با تأثير تغييرات دما بر شكل

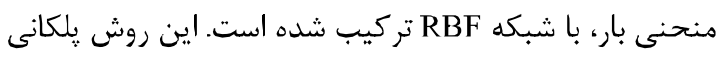

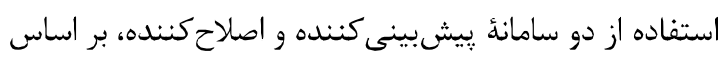

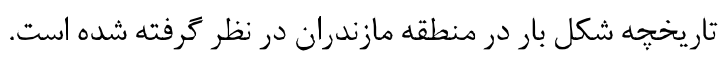

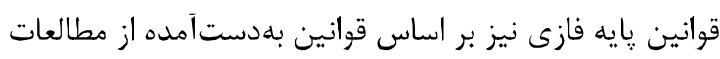

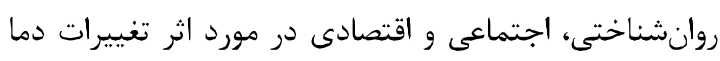

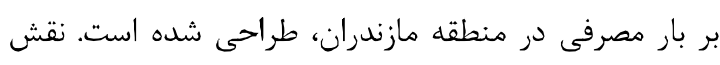

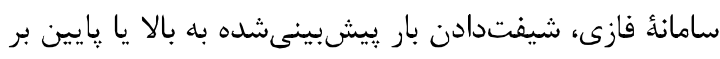

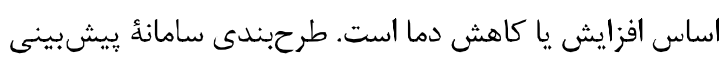

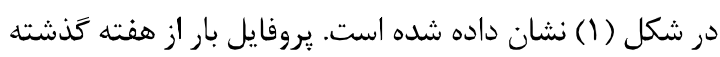

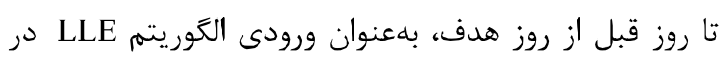

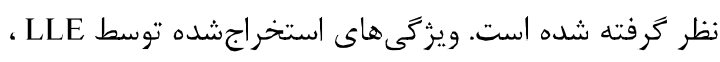

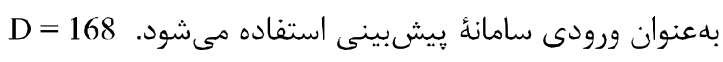
و برابر با تعداد روزها است.

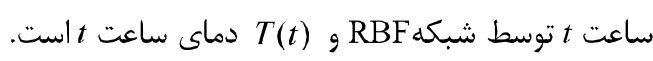

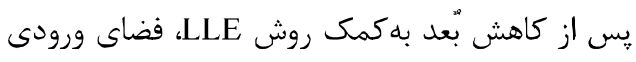

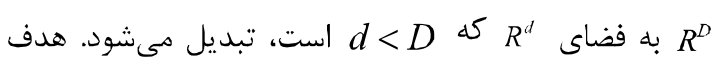

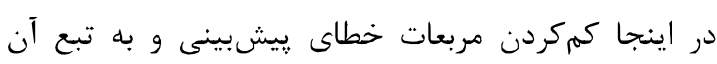

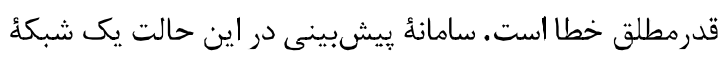

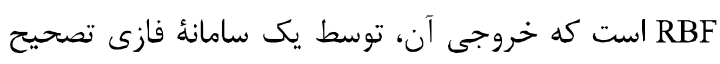

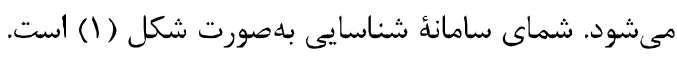

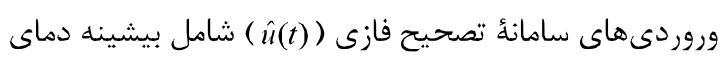

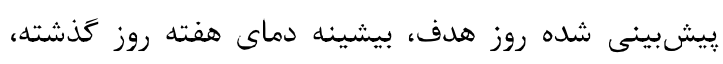

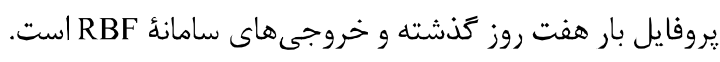
خروجى هاى سامانه فازى، خروجى هاى تصحيحشدة سامانئ

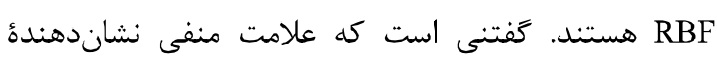
ساعتهاى قبل از روز هدف است.
كه دربردارنده ضرب داخلى $y_{i}$ مربعى با بعد N است و از رابطه زير بلهدست مى مآيد آيد: $M_{i j}=\delta_{i j}-w_{i j}-w_{j i}+\sum_{k} w_{k i} w_{k,}$

كه در ${ }^{2}$

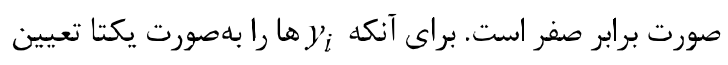
كنيم، شروط محدودكنيده قائل مىشويم تا بهترتيب درجه آزادى انتقالى و كردشى را

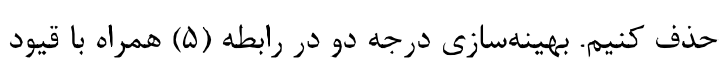

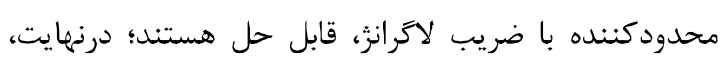

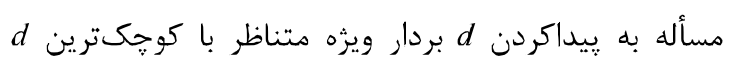

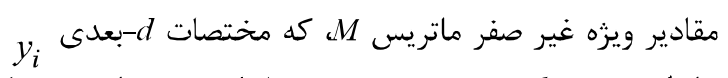

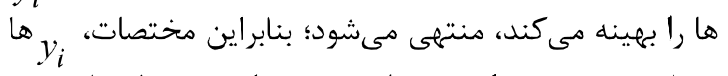

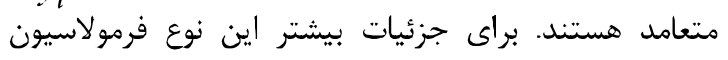
مسأله، به [11] مراجعه كنيد. يس از كاهش بعد توسط روش LLE، فضاى ورودى ازئ $\left(y_{1}, y_{2}, \ldots, y_{N}\right) \in R^{d} \quad$ به مى كند كه $d<D$ است.

روش LLE هيجتونه مدل احتمالى را بر دادهها تحميل

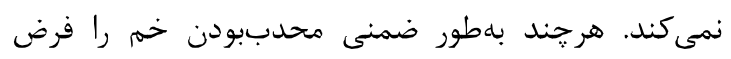
مى كند.

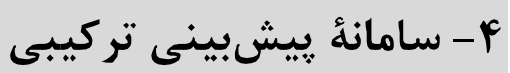

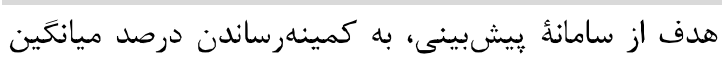

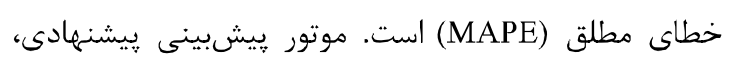

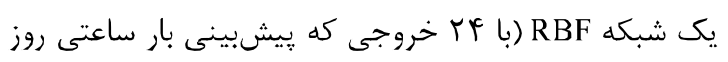

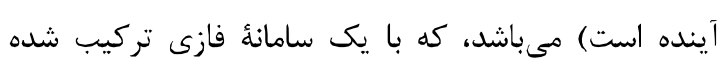

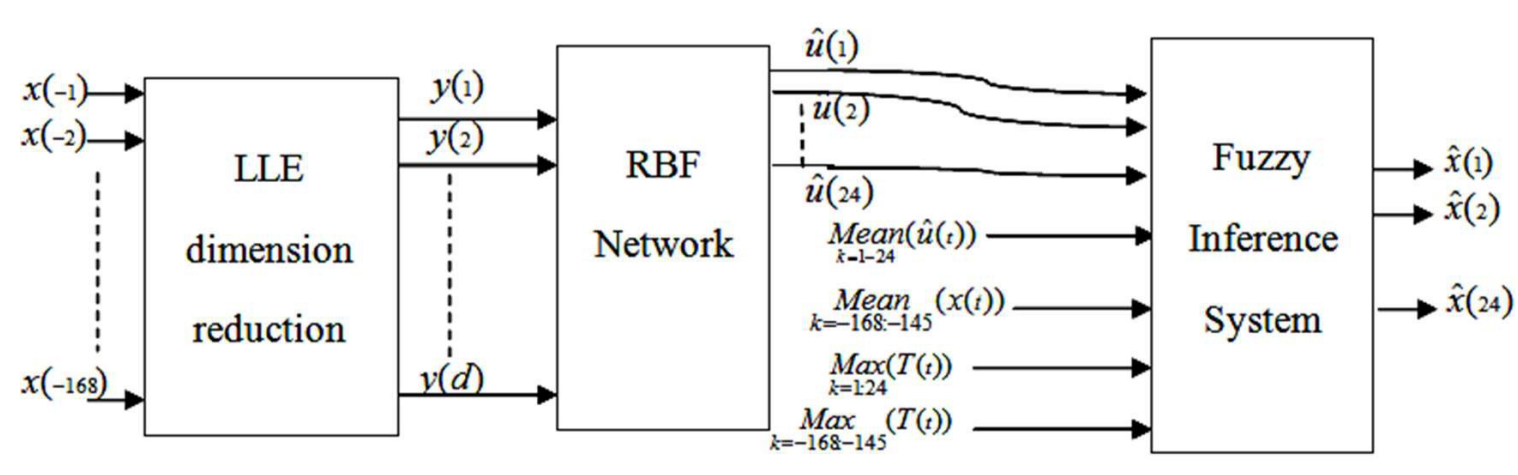

(شكل - (1): طرحبندى سيستم ييشبينى بيشنهادى

(Figure-1): The schematic of the proposed prediction system 
ساعت و انديس k به به شماره داده (كه در بخش ب مطرح

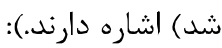

$E_{L}=\underset{k-1: 24}{\operatorname{Mean}}(\hat{u}(t))-\underset{k-168:-145}{\operatorname{Mean}}(x(t))$

$E_{T}=\underset{k=1: 24}{\operatorname{Max}}(T(t))-\operatorname{Max}_{k=-168:-145}(T(t))$

بلعبارت ديخر تفاضل مقدار ميانگين بار ويشبينى

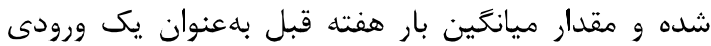

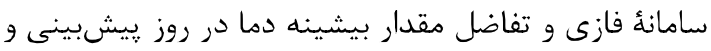
مقدار بيشينه دما هفته قبل بلهنوان ورودى ديخر سامانئ فازى در نظر كرفته شده است.

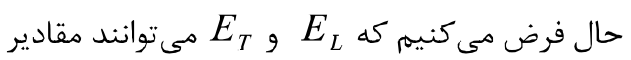

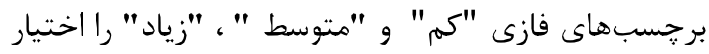

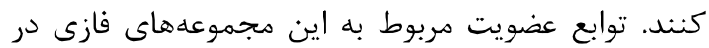
شكلهاى (T) و (T) نمايش داده شده است.

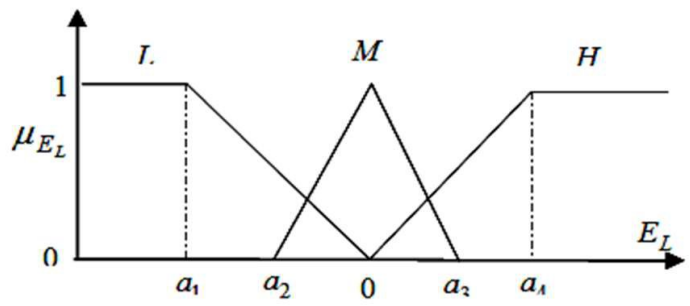

(EL) (شكل - (r) : توابع عضويت ورودى نخست

(Figure-2): The membership functions for $\mathbf{E L}$

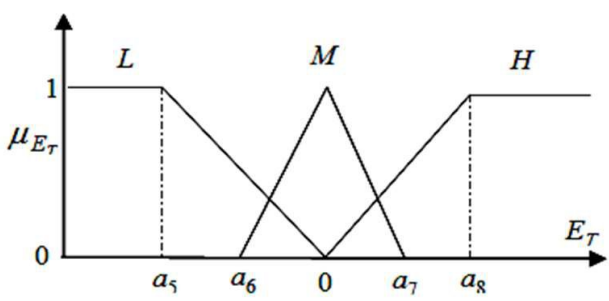

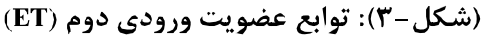

(Figure-3): The membership functions for ET

همجنين خروجى اين سيستم فازى (a) نيز با توابع ذوزنقهاى به صورت زير بيان مىشود:

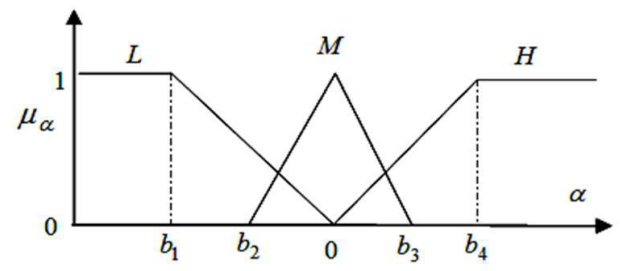

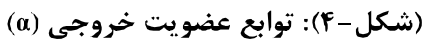

(Figure-4): The fuzzy output ( $\alpha$ ) membership function
RBF شبكه - F-1

براى آموزش شبكة RBF، روشهاى مختلفى وجود دارد.

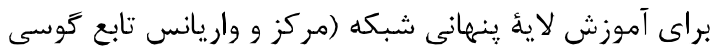

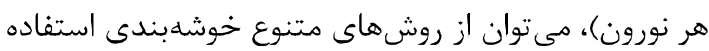

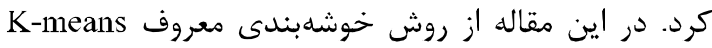
براى محاسبه مراكز توابع گوسى استفاده شده است. واريانس رونس هر تابع گَوسى را مى توان بلهصورت ذهنى مرابع دحاسبه كرد.

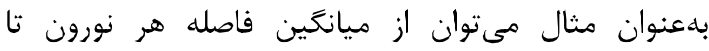
نورونهاى ديخر، استفاده كرد. بهطور همارز: $\sigma_{i}=\underset{j}{\operatorname{Mean}}\left(\left\|c_{i}-c_{j}\right\|\right), j=1,2, \ldots, m$ كه m تعداد نورونها و مركز هر خوشه، بردارى با d مؤلفه $c_{i}=\left(c_{i 1}, c_{i 2}, \ldots, c_{i d}\right) i=1,2, \ldots, m$

بعد از خوشهبندى فضاى ورودى و محاسبه مراكز و واريانسهاى توابع گَوسى تمام نورونها، خروجى هر نورون

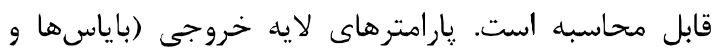
وزنها) با روشهاى بهينهسازى مبتنى بر كراديان قابل باديل تخمين هستند. در اين مقاله براى تخمين وزنهاى لايه

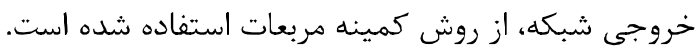

\section{r}

بار الكتريكى در مناطق مرطوبى كه در آنها دما نوسان

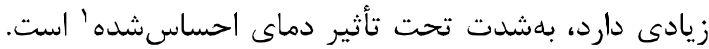
در اين مقاله، اثر دما (بهعنوان عامل غالب براى تنظيم مقددار

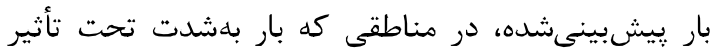
شرايط آب و هوايى است)، از طريق استفاده از يك سامانئ خبره فازى مورد بررسى قرار مى كيرد.

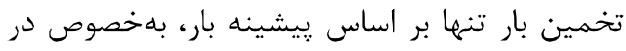

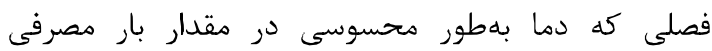
تأثير كذار است، موجب خطاى زيادى در يِيشبينى بار است.

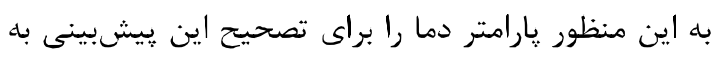

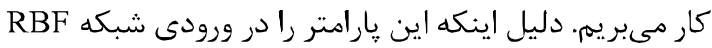

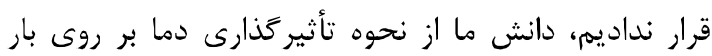
است. به همين منظور، تصحيح بار به كمك يك سامانهُ خبره فازى صورت مى اين سامانٔ فازى از نوع ممدانى ^ است و دو ورودى (شكل(1) بهصورت زير دارد (توجه كنيد كه انديس t بـ له له

${ }^{1}$ Feeling temperature

${ }^{2}$ Mamdani-type Fuzzy system 
روزانه براى سالهاى F ع و هم، از يازدهم ارديبهشت تا نهم

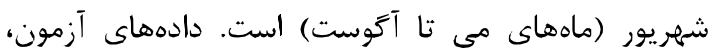

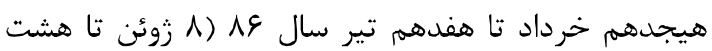

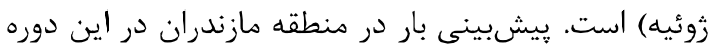

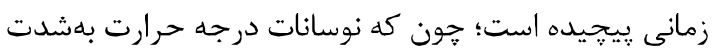

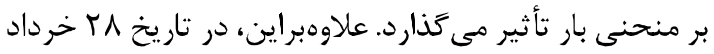

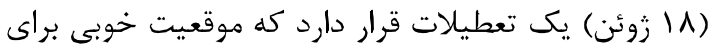
آزمايش روش يِيشنهادى ما است.

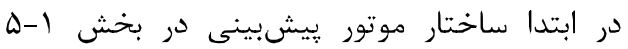

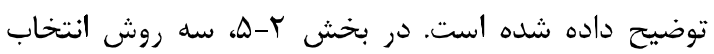

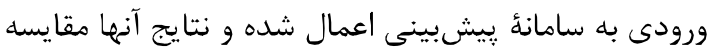

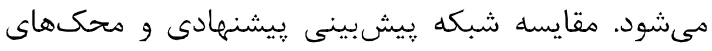

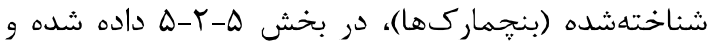

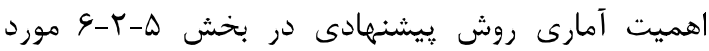

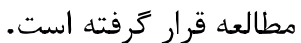

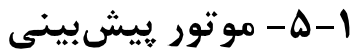

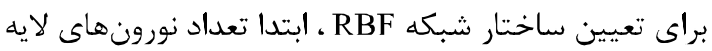

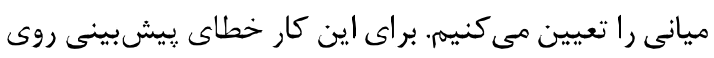

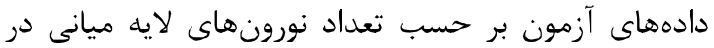
شكل زير رسم شده است. درنتيجه، تعداد نورونهاى لائ لائ لادئ

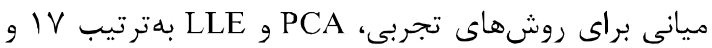

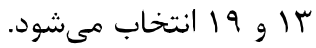

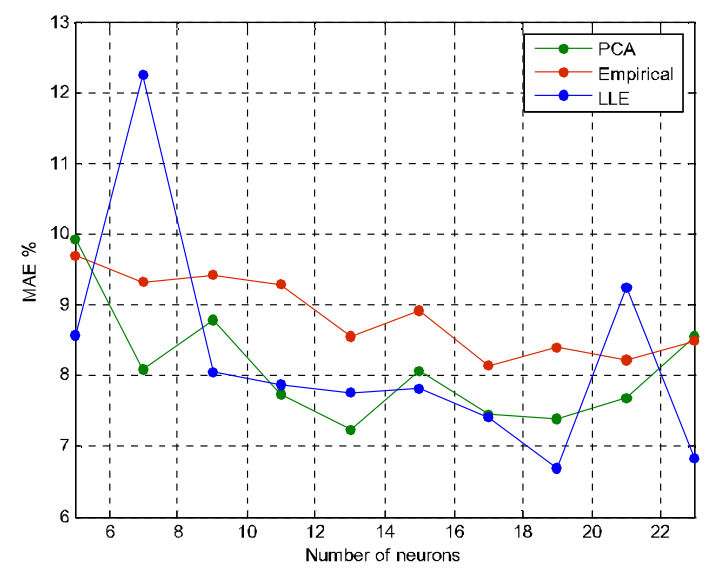

(شكل - ه): ميانغين قدرمطلق خطاى بيشبينى بر حسب تعداد

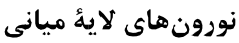

(Figure-5): The mean absolute error of prediction versus number of neurons

مراكز اين نورونها را نيز مى توان بلهوسيلئ روش خوشهبندى K-means تعيين كرد. واريانس هر تابع كوسى انسى

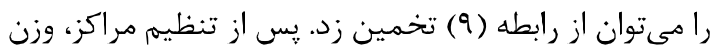

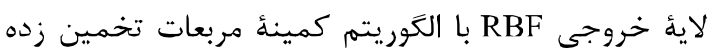

قوانين اين سامانُٔ فازى، بر اساس دانشى كه در مورد

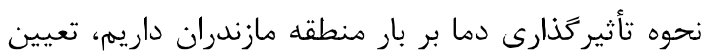
مىشود. اين قوانين در جدول زير آمده است:

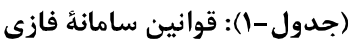

(Table-1): Fuzzy rule Base

\begin{tabular}{|c|c|c|c|}
\multicolumn{5}{|c|}{ (Table-1): Fuzzy rule Base } \\
\hline RULES & $E_{L}$ & $E_{T}$ & $\alpha$ \\
\hline R1 & L & L & M \\
\hline R2 & L & M & M \\
\hline R3 & L & H & H \\
\hline R4 & M & L & L \\
\hline R5 & M & M & M \\
\hline R6 & M & H & M \\
\hline R7 & H & L & L \\
\hline R8 & H & M & L \\
\hline R9 & H & H & M \\
\hline
\end{tabular}

حال با توجه به اين كه درجه عضويت بهترتيب

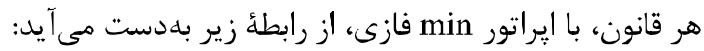

$\mu_{i}=\operatorname{Min}\left(\mu_{E_{L}}(i), \mu_{E_{T}}(i)\right)$

در عبارت بالا $i$ به شماره قانون اشاره مىكند و در

هر قانون (r) نشان داده شده است، نمايانكر درجه عضويت H

در نهايت خروجى سامانهُ فازى كه ضريب تصحيح

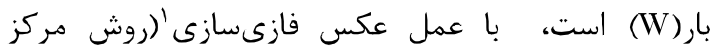
ميانخين) بر اساس رابطه زير بهدست مى آيد: $W=\frac{\sum_{i=1}^{9} C_{\alpha_{i}} \mu_{i}}{\sum_{i=1}^{9} \mu_{i}}$

در رابطةٔ بالا

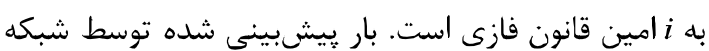
RBF

$\hat{x}(t)=(1+W) \cdot \hat{u}(t)$

در رابطؤ بالا، (t) بار پِيشبينى شده براى ساعت t است.

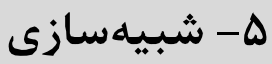
هدف از اين شبيهسازى، بيشبينى بار الكتريكى يكى روز

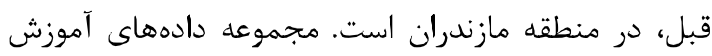

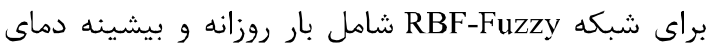

1 Defuzzification 
شبيهسازى نمى افزايد؛ همجنين انتخاب تعداد كمتر از سه

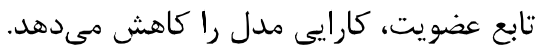

\section{ץ- - - روش هاى انتخاب ورودى}

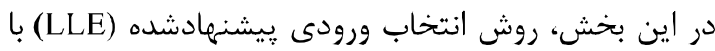

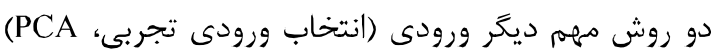

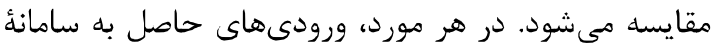

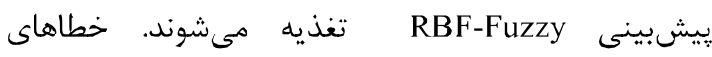
بيشبينى محاسبه شده و ميانكَين قدر مطلق درصد خطاها

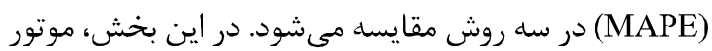

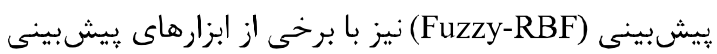

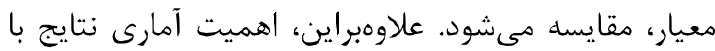

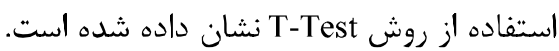

|

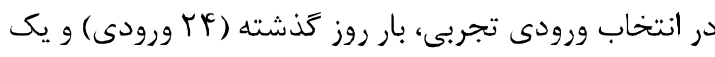

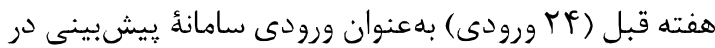
نظر گرفته شده است. بار روز كذشته بهعلت نزديكى به به روز

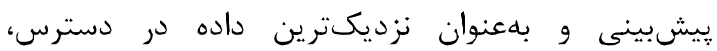

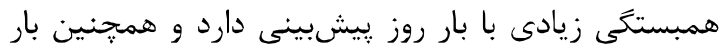

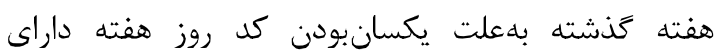
همبستى زيادى با بار روز زيشيشينى است. همجنين

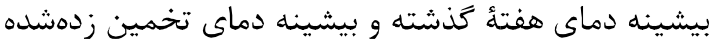

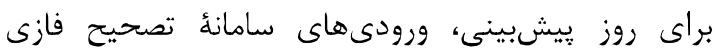

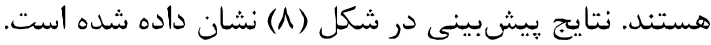

مىشود. خروجى شبكة RBF توسط سامانه فازى استفاده مىشود. مقادير ثابت توابع عضويت ورودى و خ خروجى در

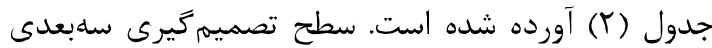

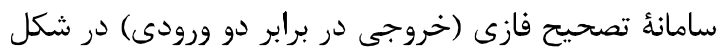
(ع) نشان داده شده است. مقادير مختلف ضر يب تصحيح بار (W) در مقادير مختلف ورودى، بهدست آورده مىشود.

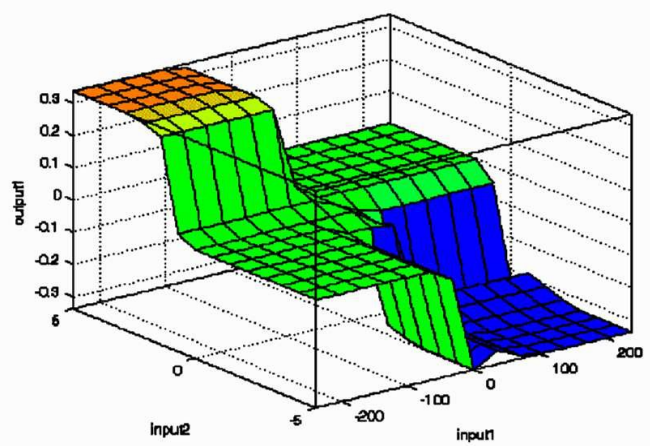

(شكل - \&): سطح تصميم كيرى سه بعدى سيستم فازى :

(Figure-6): 3D decision surface of the fuzzy system

توابع عضويت فازى با توجه به محدوده دادههاى ورودى ( تعيين شده است. به اين ترتيب كه ابتدا با توجه به محدا تغييرات، بازهاى شده و سيس هر يك از اين محدودهها با سه تابع عضويت

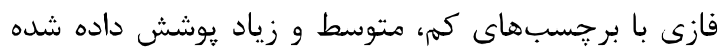

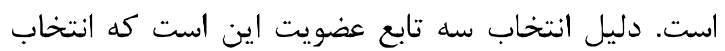

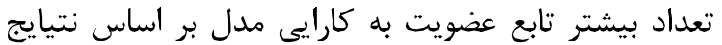

(جدول-r): مراكز توابع عضويت ورودى ها و خروجى

(Table-2): Input and output membership functions' centers

\begin{tabular}{|c|c|c|c|c|c|c|c|c|c|c|c|c|}
\hline Parameter & $\mathbf{a}_{1}$ & $\mathbf{a}_{2}$ & $\mathbf{a}_{3}$ & $\mathbf{a}_{4}$ & $\mathbf{a}_{5}$ & $\mathbf{a}_{6}$ & $\mathbf{a}_{7}$ & $\mathbf{a}_{8}$ & $\mathbf{b}_{1}$ & $\mathbf{b}_{2}$ & $\mathbf{b}_{3}$ & $\mathbf{b}_{4}$ \\
\hline Value & $\mathbf{- 1 0 0}$ & $\mathbf{- 5 0}$ & $\mathbf{5 0}$ & $\mathbf{1 0 0}$ & $\mathbf{- 3}$ & $\mathbf{- 1}$ & $\mathbf{1}$ & $\mathbf{3}$ & $\mathbf{- 0 . 5}$ & $\mathbf{- 0 . 5}$ & $\mathbf{0 . 5}$ & $\mathbf{0 . 5}$ \\
\hline
\end{tabular}

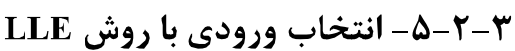
انتخاب ورودى توسط LLE مشابه روش PCA است. أبت ابعاد

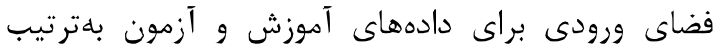

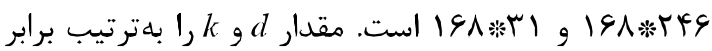

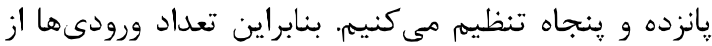

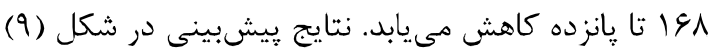
نشان داده شده است.

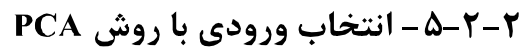

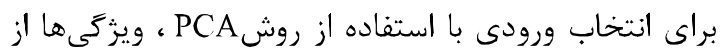

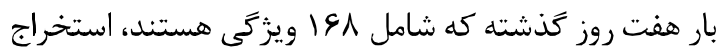

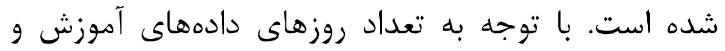

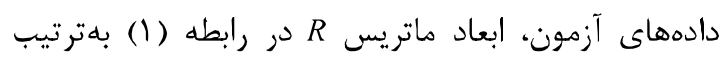
191*FF9

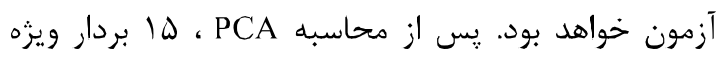

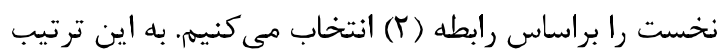

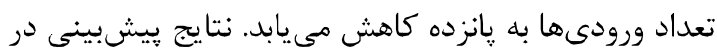
شكل (^) نشان داده شده است. 

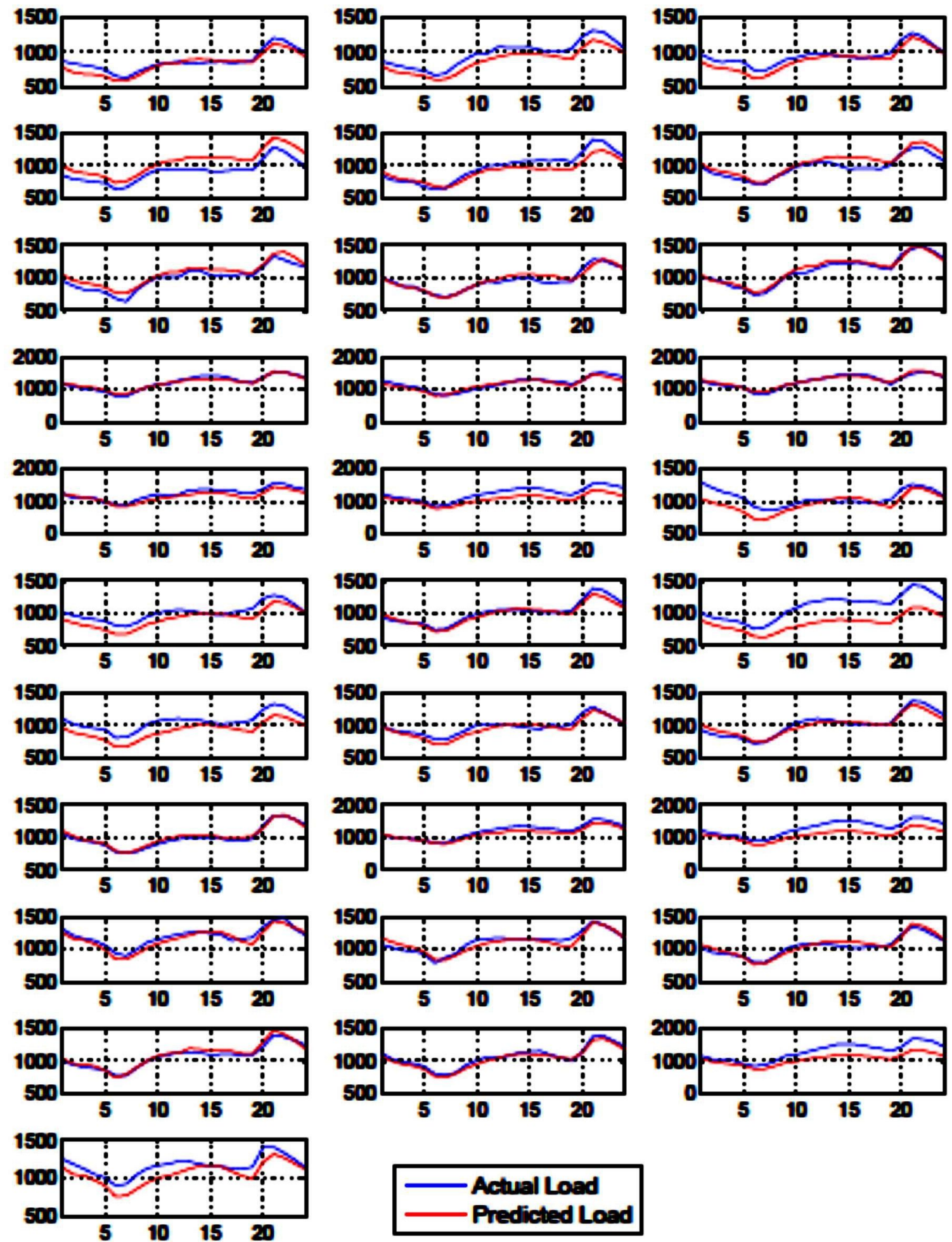

(شكل - V): مقايسه بين منحنى بار واقعى و منحنى بار بيشبينى شده (مقدار بار روزانه بر حسب ساعت) براى دوره يك بماهد، زمانى كه انتخاب ورودى بdصورت تجربى انجام مىشود و ييشبينى توسط شبكه Fuzzy-RBF انجام ميى شود

(Figure-7): comparison between actual load curves and predicted load curves when input selection is carried out empirically and prediction is carried out by RBF network- 

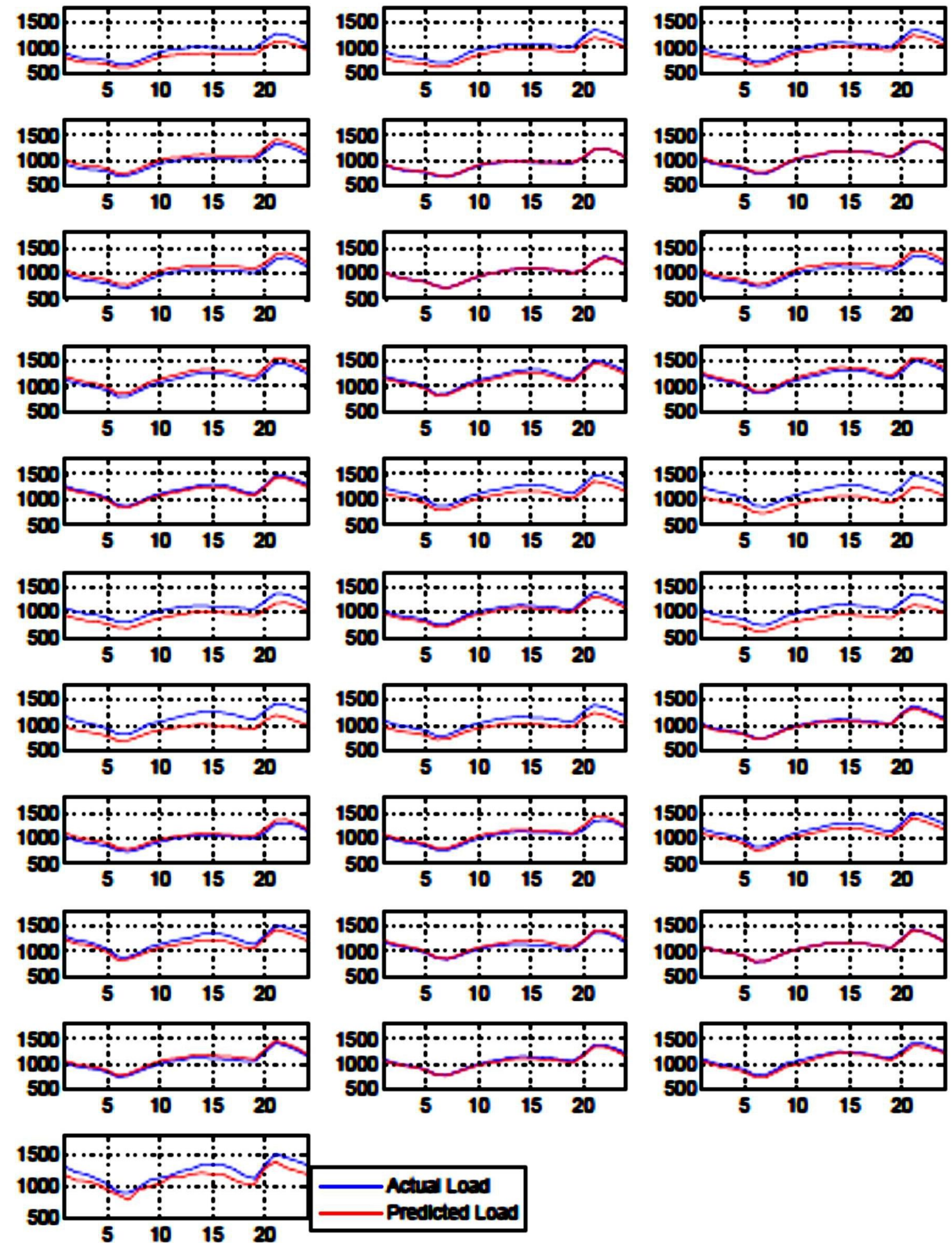

(شكل -1): مقايسه بين منحنى بار واقعى و منحنى بار بيشبينىشده (مقدار بار روزانه بر حسب ساعت) براى دوره يكـاهه، بر اساس انتخاب ورودى بلروش PCA و رييشبينى توسط شبكه Puzzy-RBF

(Figure-8): comparison between the actual load curves and the predicted load curves based on PCA input selection and prediction by RBF-fuzzy system. 

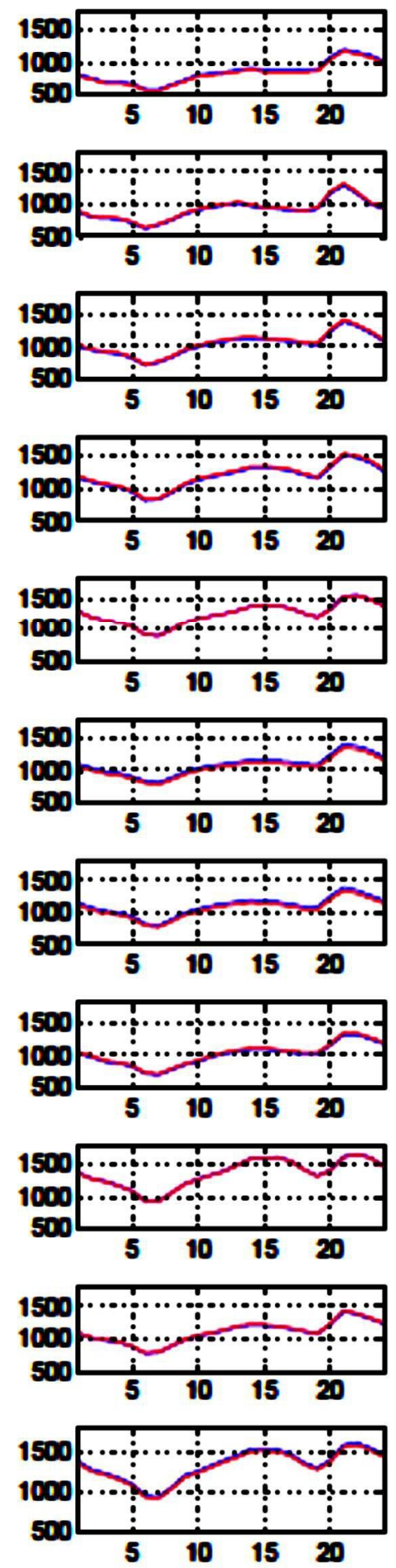
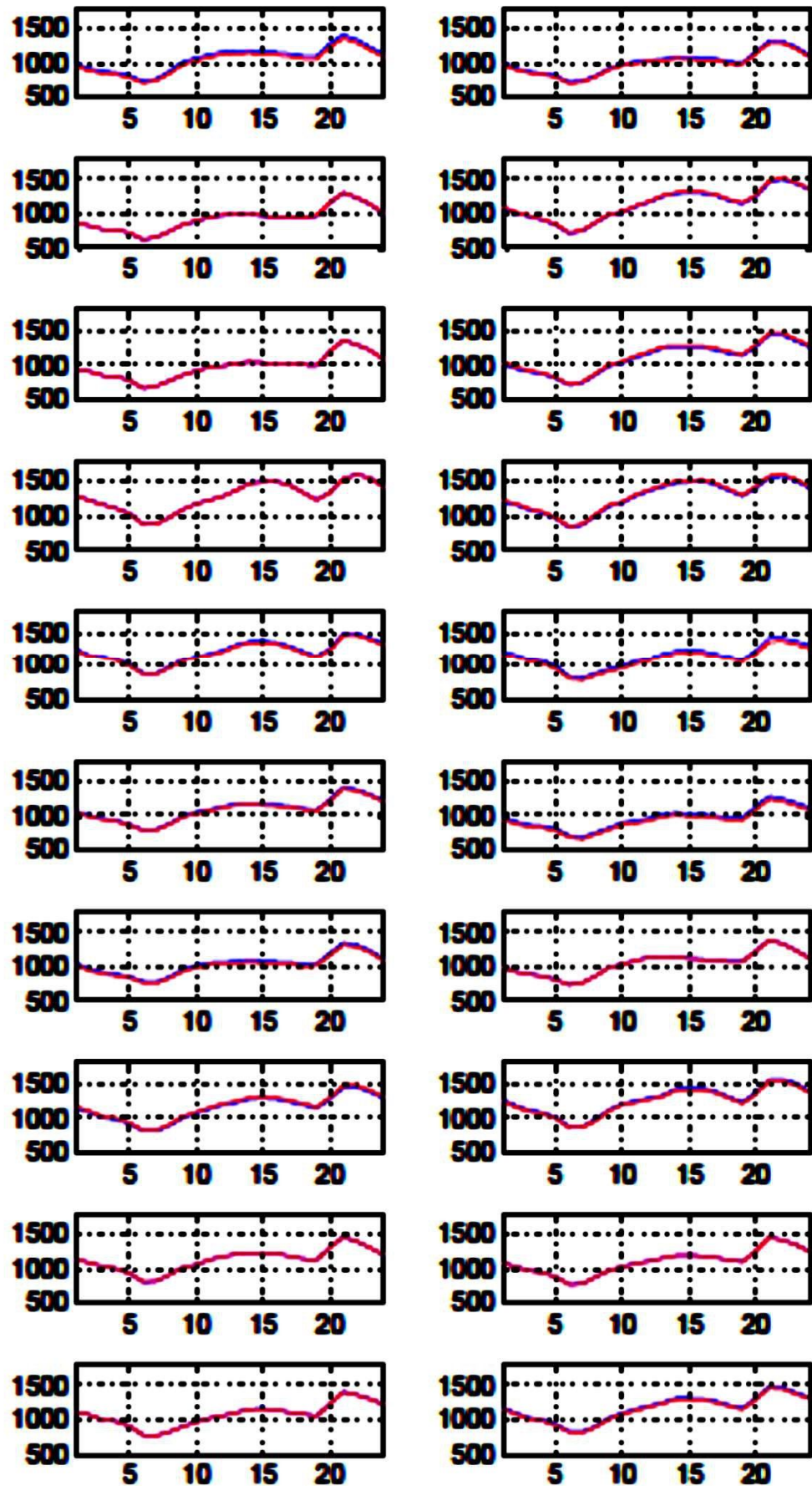

(شكل - 9): مقايسه منحنى بار واقعى و منحنى بار پيشبينى شده (مقدار بار روزانه بر حسب ساعت) براى دوره يكـاهه، بر اساس

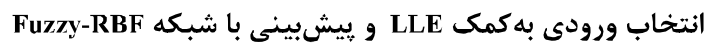

(Figure-9): comparing actual load curves and predicted load curves based on LLE input selection and RBF-fuzzy prediction system. 
يِيشنهادى در نظر كرفته شده است، كه عبار تند از شبكههاى

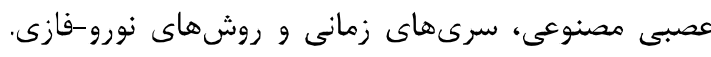

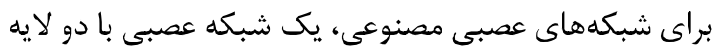

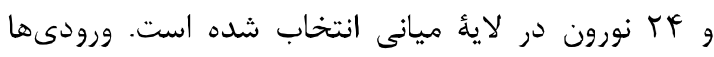

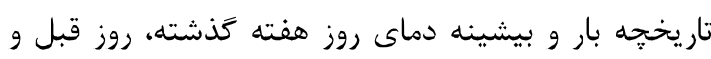

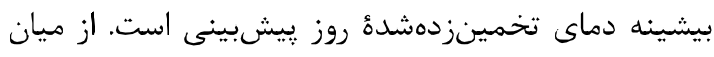

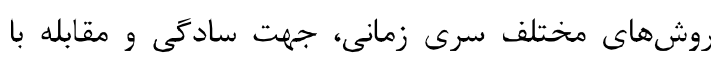

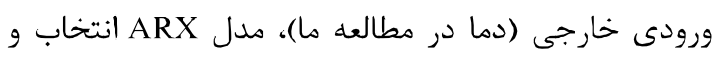

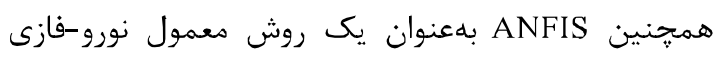

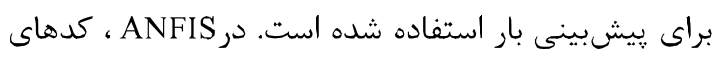

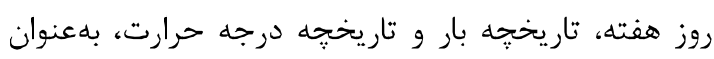

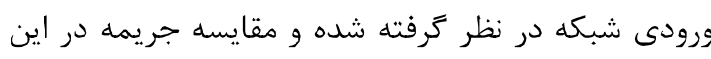
روشها در جدول (rا) آمده است.

(جدول - (T): مقايسه عملكرد روش هاى يِيشنهادى

(Table-3): Comparing the performance of proposed

\begin{tabular}{|c|c|c|}
\hline & $\begin{array}{c}\text { approaches } \\
\text { Mverage }\end{array}$ & $\begin{array}{c}\text { Maximu } \\
\text { m MAPE }\end{array}$ \\
\hline Fuzzy-RBF & $4.12 \%$ & $9.15 \%$ \\
\hline RBF & $5.95 \%$ & $10.18 \%$ \\
\hline ANN & $5.869 \%$ & $12.91 \%$ \\
\hline ARX & $4.85 \%$ & $10.03 \%$ \\
\hline ANFIS & $5.60 \%$ & $13.94 \%$ \\
\hline
\end{tabular}

نتايج نشان مى دهد كه شبكه RBF-Fuzzy نسبت به

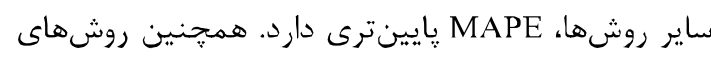
ANN ، ARX روش RBF (با استفاده از درجه حرارت بهعنوان ورودى)

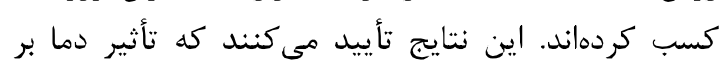
نوسانات بار مازندران، بسيار زياد است. نتاني

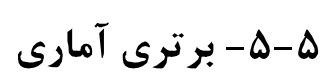

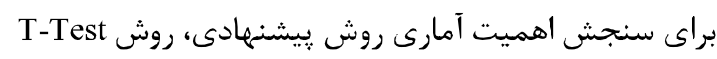

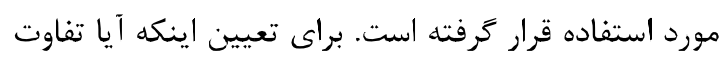

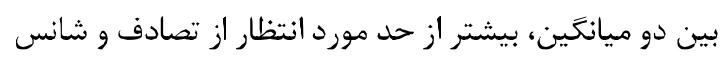

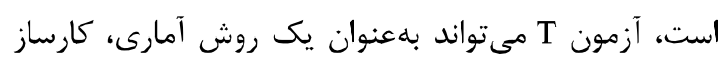

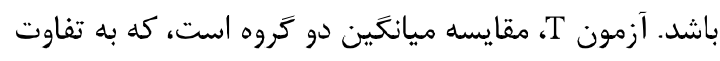

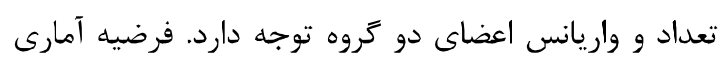

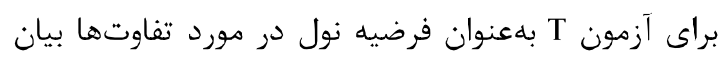

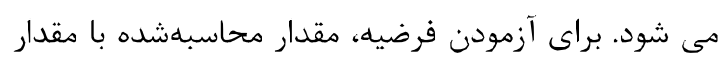

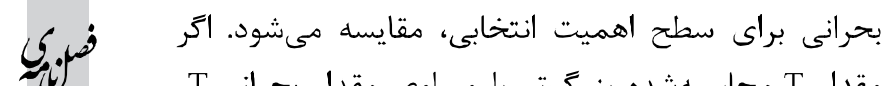

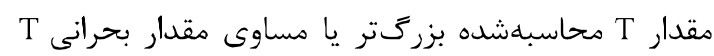

\section{ץ-ه- نتايج مقايسهاى}

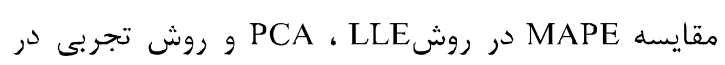

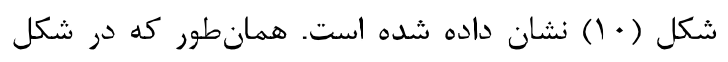

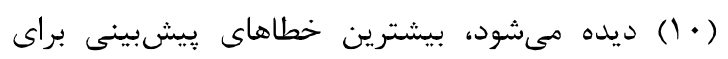

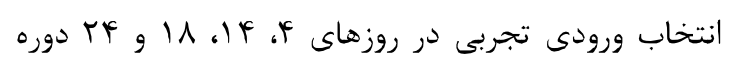

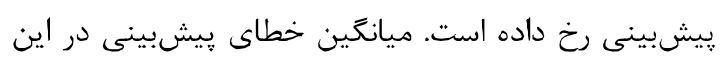

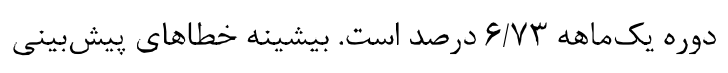

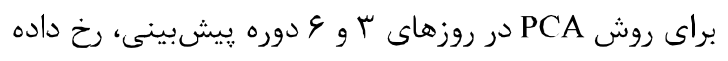

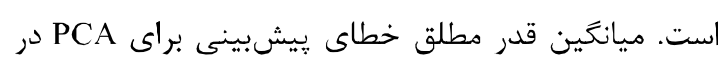

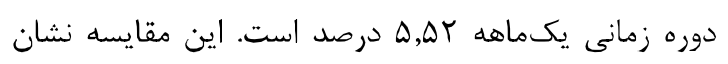

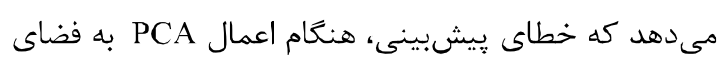

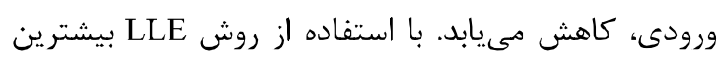

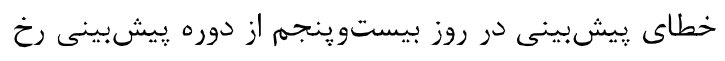

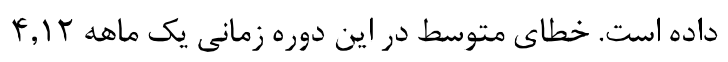

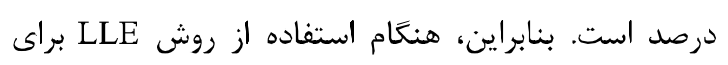

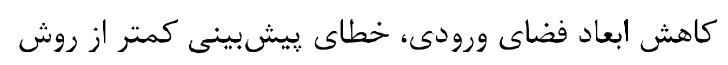

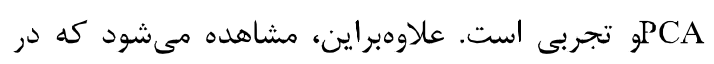

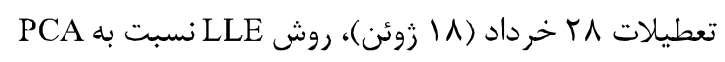

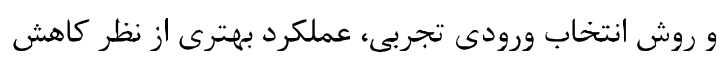
خطاى بيش وبينى داشته است.

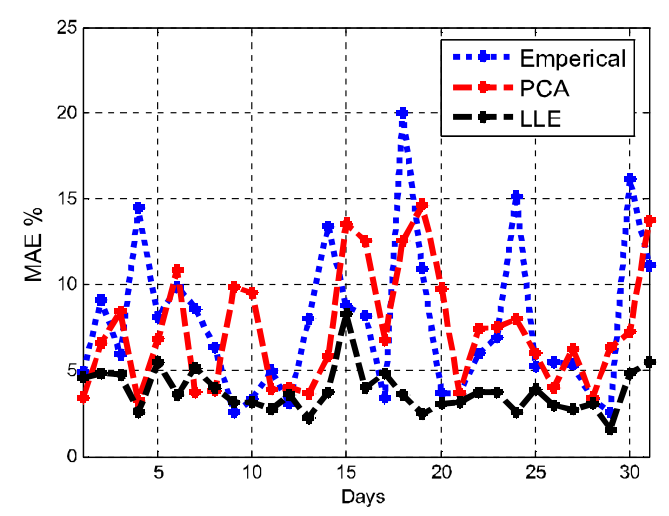

(شكل - •(): مقايسه ميانخين قدر مطلق خطاى پيشبينى در هر

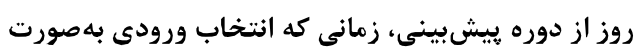

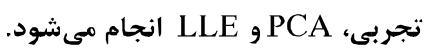

(Figure-10): Comparing average absolute prediction error in each day of prediction, when input selection is carried out empirically, based on PCA and LLE methods.

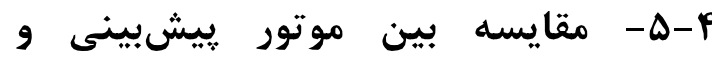 روش هاى معيار}

در اين بخش هندين مطالعه تطبيقى براى ارزيابى كارايى معيى

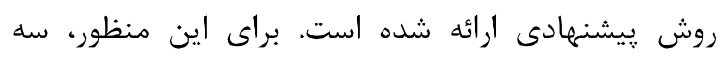

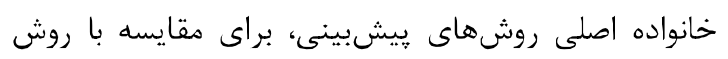


ورودى ييشنهادشده با يك موتور ييشبينى تركيبى همراه

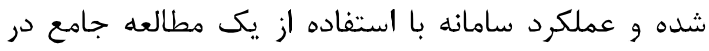

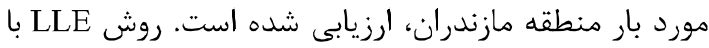

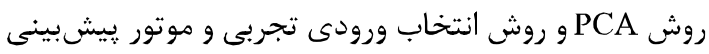
نيز با جند ابزار شناختهشده يِيشبينى، مقايسه شده و نشان

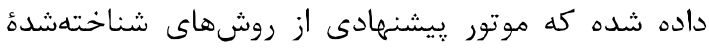

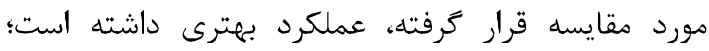
همجنين، روش LLE به روش PCA و روش انتخاب ورودى مورى

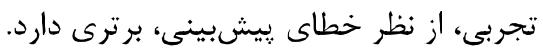

\section{7- References}

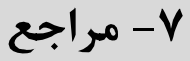

[1]D. Liang, M. Zhichun, "Short-term load forecasting based on fuzzy neural network," Journal of University of Science and Technology Beijing, 4, pp. 46-49, 1997.

[2] K.H Kim, H.S Youn, Y.C. Kang, "Short-term Load Forecasting for Special Days in anomalous Load Conditions Using Neural Network and Fuzzy Inference Method," IEEE Transactions on Power Systems, vol.15, pp. 559-569, 2000.

[3] W. Charytoniuk, M. S. Chen, "Neural Network design for Short-Term Load Forecasting," Proceedings of International Conference on Electric Utility Deregulation and Restructuring and Power Technologies, London, pp. 4-7, 2000.

[4] Z. Tao, Z. Dengfu, Z. Lin, W. Xifan, X. Daozhi, "Short-Term Load Forecasting Using Radial Basis Function Networks and Expert system," Journal of XI'AN JIAOTONG University, vol.35, pp. 331-334, 2001.

[5] Z. Xin, C. Tian-Lun, "Nonlinear Time Series Forecast Using Radial Basis Function Neural Network," Commun. Theor. Phys, vol.40, pp.165-168, 2003.

[6] V. S. Kodogiannis, E. M. Anagnostakis, "Soft computing based techniques for short-term load forecasting," Fuzzy Sets and Systems 128(3), pp. 413-426, 2002.

[7] R.R.B. de Aquino, et.al, "Combined Artificial Neural Network and Adaptive Neuro-Fuzzy Inference System for Improving a Short-Term Electric Load Forecasting," Lecture Notes in Computer Science, 4669, 779-788, 2007.

[8] Musa, Abdallah Bashir. "A comparison of $\ell 1$ regularizion, PCA, KPCA and ICA for dimensionality reduction in logistic regression." International Journal of Machine Learning and Cybernetics 5.6, pp.861-873, 2014.

[9] L. Cayton, Algorithms for manifold learning, University of California, San Diego, Tech. Report, 2005.
باشد، فرضيه نول رد شده و نتيجه گرفته مىشود كه ميزان

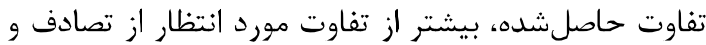
شانس است. اگر مقدار T محاسبهشده كوجكتر از مقدار بحرانى T باشد، فرضيه نول رد نشده و نتيجه ميى معدرد كه اين مقدار اختلاف، مىتواند نتيجه شانس و تصادف باشد [21]. مقادير بحرانى T براى مقادير مختلف سطوح اهميت

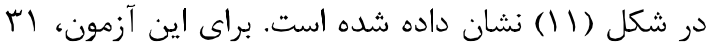
روز بازه مورد مطالعه، استفاده شده است. سطح اهميت روش ييشنهادى Fuzzy-RBF از نظر MAPE با ساير روشها مقايسه شده است. سطوح اهميت در جدول (f) آمده است.

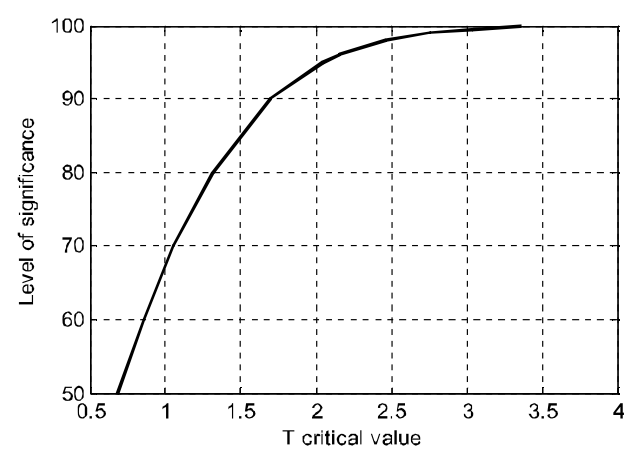

(شكل - (1): نمودار بحرانى مقادير T در سطوح مختلف اهميت (Figure-11): The critical diagram of "T" values in different levels of significance.

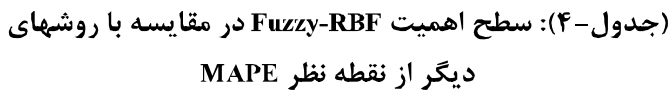

(Table-4): Level of significance of Fuzzy-RBF in comparison \begin{tabular}{|c|c|c|c|c|}
\hline \multicolumn{1}{|c}{ with other methods (In sense of MAPE) } \\
\hline $\begin{array}{c}\text { Fuzzy- } \\
\text { RBF }\end{array}$ & 0.96 & 0.94 & 0.906 & 0.954 \\
\hline
\end{tabular}

\section{9- نتيجه}

ورودىهاى موتور پيشبينى، پايه تخمين است و موتور

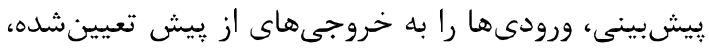

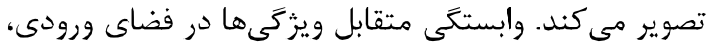
منجر به افزايش ابعاد ورودى، بدون افزايش اطلاعات مؤثر،

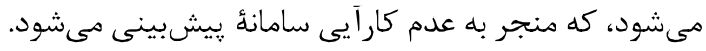

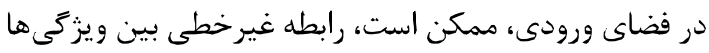

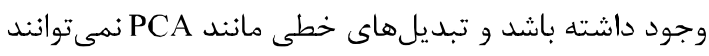
جنين وابستخىىهاى غير خطى را يِيدا كنند. در اين مقاله

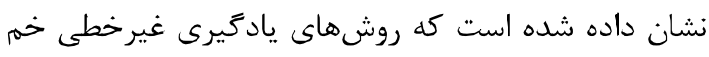

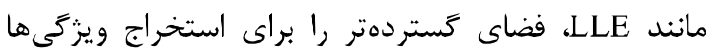

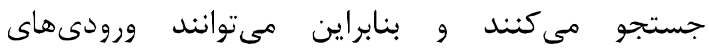
مناسبترى را براى پيشبينى بار پيدا كنند. روش انتخاب 
load and neural networks," Journal of Modeling in Engineering, vol.15 (16), 2007.

$$
\begin{aligned}
& \text { [rr] سيد شنوا سيد جلال، قاسمى على، شايقى حسين و } \\
& \text { نوشيار مهدى. ارايه يك مدل تركيبى در هيشبينى بار }
\end{aligned}
$$

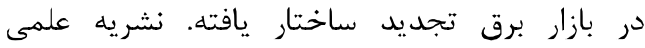

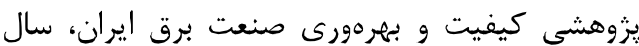

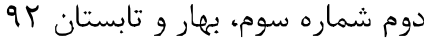

[23] S.sh. Seyed Jalal, et al, “A Composite Model for Load Forecasting in the Restructured Electricity Market," Journal of Quality and Productivity in Iran Electric Industry, vol.2(3), 2013.

$$
\text { [Tf] مشارى امير، ابراهيمى اكبر، صدرى سعيد، ابراهيمى }
$$

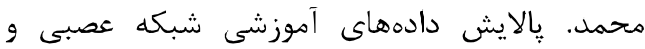

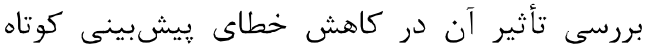$$
\text { مدت بار سيستمهاى قدرت. نشريه استقلال. سال ^رئ. }
$$

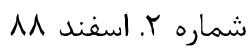

[24] A. Moshari, et al., "Purification of Neural Network Train Data and its Effect on Reducing Short-Term Prediction Errors of Power Systems," Esteghlal Magazine. vol.28 (2), 2009.

[ro] شايقى حسين، قاسمى على. مدلسازى سيستم جند

ورودى جند خروجى براى پيش بينى همزمان قيمت

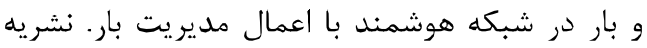

هوش محاسباتى در مهندسى برق. سال ششم، شماره

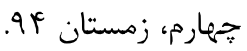

[25] II. Shayeghi, et al, "Multi-Input Multi-output System Modeling for simultancous prediction of price and load in the smart grid by applying load management," Journal of Computational Intelligence in Electrical Engineering, Vol. 6 (4), 2015.

[عr] كريمى مازيار، كرمى حسين، غلامى مصطفى، خطيب

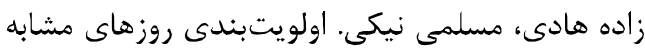

جهت پِيشبينى بار كوتاه مدت شبكه ايران با در نظر

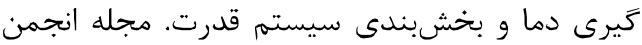

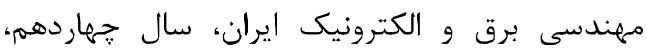

$$
\text { شماره سوم، ياييز } 99
$$

[26] M. Karimi , et al., "Prioritizing the same days to predict the short-term load of Iran's network by considering the temperature and power system segmentation," Journal of Iranian Association of Electrical and Electronics Engineers. Vol. 14 (3), 2016.

قانعى يخدان حسين. روشى جديد براى اختفاى خطا

در فريمهاى ويدئو با استفاده از شبكه عصبى روسيى
[10] I. Borg and P. Groenen, Modern Multidimensional Scaling: Theory and Applications. New York: Springer-Verlag, 1997.

[11] J. B. Kruskal, "Multidimensal scaling by optimizing goodness of fit to a nonmetric hypothesis," Psychometrika, vol.29, pp. 1-27, 1964.

[12] Ji, Rongrong, et al, "Towards Optimal Manifold Hashing via Discrete Locally Linear Embedding," IEEE Transactions on Image Processing, 2017.

[13] Liu, Xin, et al, "Locally linear embedding (LLE) for MRI based Alzheimer's discase classification," Neuroimage, vol. 83, pp.148157.2013 .

[14] J. Yang, B. Ming Xiang, and Y. Zhang, "Multimanifold Discriminant Isomap for visualization and classification," Pattern Recognition, vol. 55, pp. 215-230, 2016.

[15] M. Belkin , and P. Niyogi, "Laplacian eigenmaps for dimensionality reduction and data representation," Neural Compute, vol. 15(6), pp. 1373-1396, 2003.

[16] Ye. Qiang, and W. Zhi, "Discrete hessian eigenmaps method for dimensionality reduction," Journal of Computational and Applied Mathematics, vol.278, pp.197-212, 2015.

[17] Su, Zuqiang, et al., "Fault diagnosis method using supervised extended local tangent space alignment for dimension reduction," Measurement, vol. 62, pp.1-14, 2015.

[18] L. Haghverdi, F. Buettner, and J. Fabian, "Diffusion maps for high-dimensional singlecell analysis of differentiation data," Bioinformatics, vol. 31.18, pp.2989-2998, 2015.

[19] Lunga, Dalton, et al. "Manifold-learning-based feature extraction for classification of hyperspectral data: A review of advances in manifold learnping," IEEE Signal Processing Magazine, vol. 31.1, pp.55-66, 2014.

[20] J. Wang, Z. Zhang, and H. Zha, "Adaptive manifold learning," In Advances in Neural Information Processing Systems, 2004.

[21] W. H Press, et al, Numerical Recipes in C: The Art of Scientific Computing, Cambridge University Press, pp. 616, 1992.

[Yr] فريبرز نيا روح الله, امجدى نيما، پيشبينى بار

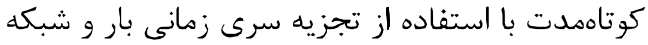

عصبى، مجله مدل سازى در مهندسى، دوره ب، شماره

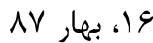

[22] R. Fariborznia, N. Amjadi, "short term load forecast by using time series decomposition of 


\section{h-kamalinejad@trec.co.ir}

$$
\text { نشانى رايانامه ايشان عبارت است از: }
$$

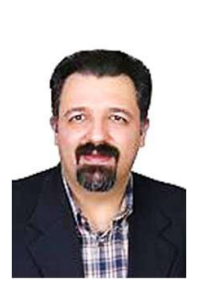

بابك نجار اعرابى دانش آموخته دكتراى تخصصى رشته مهندسى برق با كرايش يردازش سيخنال و تصوير از دانشعاه Texas A\&M حاضر ايشان استاد كروه كنترل و نيز هوش ماشين و رباتيك، در دانشكده برق و كامييوتر دانشكاه

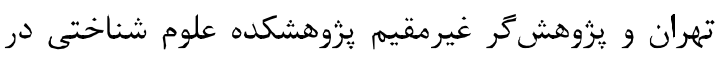

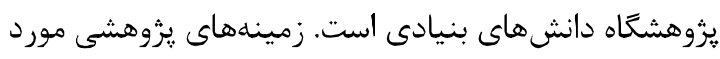

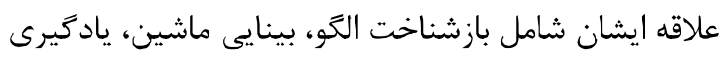
ماشين، تصميهىيرى در حضور عدم قطعيت، سامانههاى نوروفازى، تشخيص خطا، يِيشبينى و مدل سازى سامانهها

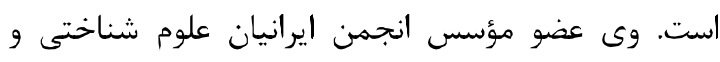
تكنولوزى و عضو هيأت مديرؤ جندين انجمن علمى است. araabi@ut.ac.ir
فصلنامه علمى - يزوهشى يردازش علائم و دادهها،

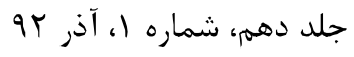

[27] H. Ghanei yakhdan, "A new method to hide errors in video frames using RBF neural network," Journal of Signal and Data Processing, vol.10 (1), 2013.

[rی] Fوهريان نازنين، مقيمى سحر، غلامى مصطفى، كلانى

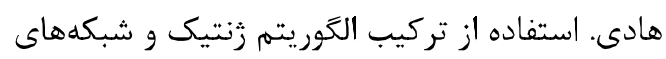

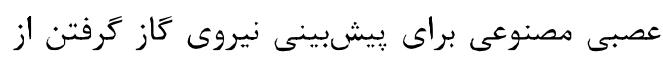

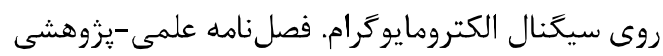

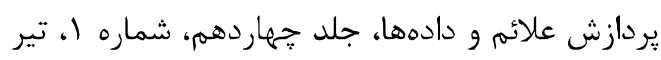

$$
\text { ماه } 94 .
$$

[28] N. Goharian, et al., "Use of combination of genetic algorithm and artificial neural networks to predict the bite force from an electromyogram signal," Journal of Signal and Data Processing, Vol.14 (1), 2017.

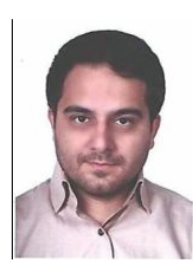

حامد كبريائى دانش آموخته مقطع دكترا در رشته مهندسى برق كنترل از دانشعاه تهران و در حال حاضر استاديار كروه

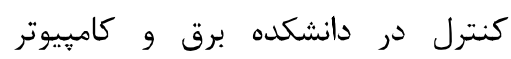

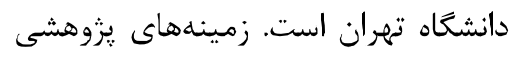

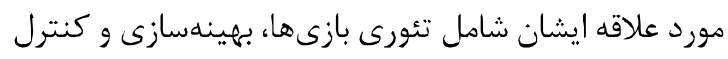

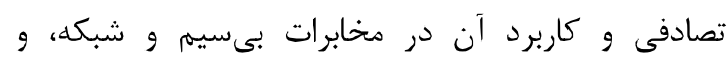
شبكه هاى الكتريكى هوشمند است. وى عضو IEEE و و كميته

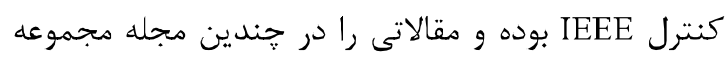

$$
\text { نشانى رايانامه ايشان عبارت است داوى كرداند. }
$$

kebriaei@ut.ac.ir

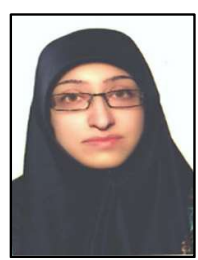

حوراء كمالسىنـزاد دانش آموخته

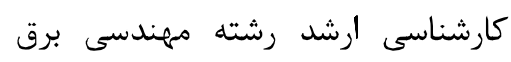

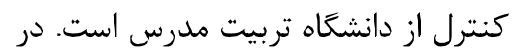

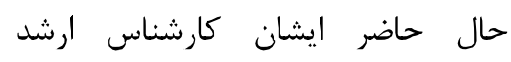

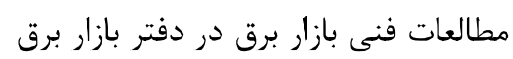

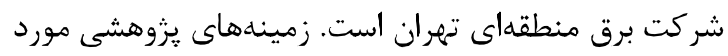

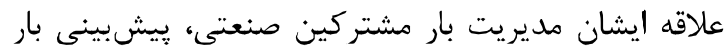

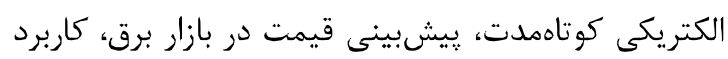

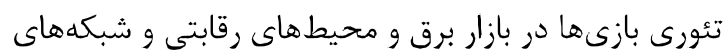
الكتر يكى هوشمند است. 